\title{
The effects of hydraulic works and wetlands function in the Salado-River basin (Buenos Aires, Argentina)
}

\author{
M. E. Bazzuri $(\mathbb{D})$ N. A. Gabellone • L. C. Solari
}

Received: 3 November 2016 / Accepted: 28 December 2017

C) Springer International Publishing AG, part of Springer Nature 2018

\begin{abstract}
Man-made activities exert great influences on fluvial ecosystems, with lowland rivers being substantially modified through agricultural land use and populations. The recent construction of drainage canals in the upper stretch of the Salado-River basin caused the mobilization of huge amounts of salts formerly stored in the groundwater. The main aim of this work was to analyze the effect of the discharges of those canals into the Salado-River water, under different hydrologic conditions, and the role of the wetlands and shallow lakes placed along the canals' system. Physicochemical variables were measured and water samples were taken during times of high water, mean flows, drought, and extreme drought. The environmental variables and the plankton development were related to the hydrologic regime and reached minimum values during floods because of low temperatures and dilution. Local effects on the water's ionic composition became pronounced during droughts because of groundwater input. Nutrient concentrations were mainly associated with point wastewater discharges. Conductivity, ion concentrations, total plankton biomass, and species richness increased in the Salado-River downstream site, after the canals' discharges. The artificial-drainage system definitely promotes the incorporation of salts into the Salado-River basin. In this scenario, a careful hydraulic management is needed to take into account this issue of secondary
\end{abstract}

M. E. Bazzuri $(\bowtie) \cdot$ N. A. Gabellone $\cdot$ L. C. Solari Instituto de Limnología Dr. Raúl A. Ringuelet, CONICET. FCNyM (UNLP), Boulevard 120 y 62, (1900) La Plata, Buenos Aires, Argentina e-mail: elisab@ilpla.edu.ar salinization that threatens the economic exploitation of the region. The wetlands present in this study acted as service environments not only helping to reduce salt, nutrient, and suspended-solid concentrations downstream but also contributing a plethora of species and plankton biomass into the Salado-River main course.

Keywords Lowland river Canalizations · Wetlands · Saline waters $\cdot$ Salinization $\cdot$ Argentine pampas

\section{Introduction}

The dynamics of fluvial ecosystems are largely dependent on the hydrologic regime and the seasonal variation in the physicochemical variables (de Cabo et al. 2003). According to Junk et al. (1989), the pulsing of a river's discharge acts as an influential forcing agent for the aquatic biota, sustaining the hydrologic connectivity and continuity between the river's course and the floodplain. Accordingly, floods, like droughts, are considered as hydrologic disturbances, characterized by a particular timing, duration plus magnitude, and associated shifts in the environmental variables (Poff et al. 1997; Schagerl et al. 2009). In addition, ecological theories applied to low-order watercourses consider that stream-corridor ecosystems are compounds of concentric subsystems (i. e., superficial, hyporheic, parafluvial, riparian), that are spatially separated but hydrologically connected. The arrangement of those landscape patches, referred to as their configuration, is closely linked to the system's response to disturbance and overall resilience (Fisher 
et al. 1998). River ecosystems are increasingly threatened by civilization (Margalef 1983), and as a consequence, their hierarchical organization and functional properties are often disrupted (Sparks 1995).

The anthropic impact on freshwater environments can be separated into two categories: chemical alteration of water quality through pollutant emission and physical degradation through human activities - e. g., deforestation, urbanization, and canalization - that modify the hydrologic and biogeochemical cycles (Zalewski 2007). Among these anthropic influences, hydraulic works may represent an additional disturbance factor that modifies the river's drainage network, morphologic aspects, and hydrologic dynamics (Weilhoefer et al. 2008; Lair et al. 2009). As a consequence, natural flow pulses are altered with a resulting reduction in the spatial heterogeneity and connectivity of the floodplain environments (Amoros and Bornette 2002). Moreover, canalizations may also accelerate the downstream transport of water, nutrients, and suspended materials, with a consequential effect on the storage and loading capacity of fluvial ecosystems (Kronvang et al. 1999).

The entrance of suspended solids, dissolved nutrients, and organic matter may lead to the eutrophication of aquatic environments (Ensign and Doyle 2006). Furthermore, nutrient enrichment degrades water quality and perturbs biogeochemical cycles, thus becoming an increasing problem in many rivers (Jarvie et al. 2002, 2008). In this regard, agriculture and urban activities are considered the major sources of $\mathrm{P}$ and $\mathrm{N}$ input into aquatic ecosystems (Carpenter et al. 1998). Excesses of $\mathrm{P}$ added to cropland may accumulate in soils, thereafter reaching lotic systems by means of erosion (Carpenter 2008). In the water, the particulate $\mathrm{P}$ is dissolved, thus becoming available for algal growth (Garnier et al. 2005).

The salinization of freshwater ecosystems is a global issue that is mainly a result of human activities (e. g., mining, irrigation, road-deicing agents, resource extraction). Salt concentrations are being increased in rivers around the world; and according to some predictions, this situation will worsen in the future because of climate change, global warming, and the increasing demands on water (Cañedo-Argüelles et al. 2013). Secondary salinization - another man-made disturbance - is a hazard for terrestrial and aquatic systems, exerting irreversible adverse effects on arable lands and ecosystem services (Herczeg et al. 2001). That perturbation constitutes a major issue in freshwater environments, since salinity represents a key biologic parameter (Williams 1999; Cañedo-Argüelles et al. 2016a) and a potential toxicant as well (Kefford et al. 2002). In lotic systems, salinity acts as an additional selective force for unidirectional flow and as such creates novel environments, consequently leading to new research (Kefford et al. 2016). Accordingly, salinity appears as a pressing disturbance for stream communities, acting at the physiologic level of the constituent biota so as to enable a species to withstand the impending stress (Schäfer et al. 2011). In view of the effects of salinization on the aquatic biota present; wetlands, streams, and riparian vegetation are the principal ecosystems at risk (Hart et al. 2003).

Wetlands represent diverse aquatic environments that exhibit a high spatial heterogeneity and biologic richness. In addition, periodic floods influence the structure and function of these ecosystems (Zalewski et al. 1998; Kiedrzyńska and Zalewski 2012). Valuable environmental functions - such as the retention of nutrients and organic matter, and the processes of degradation and transformation into biomass - take place in these unique areas, shortening the spiraling nutrient loop (Reddy et al. 1999; Hein et al. 2005; Zalewski 2007). As a consequence, wetlands are fundamental regulators of biogeochemical cycles, yet are strongly shaped by hydrology and hydrologic inputs (Reddy and De Laune 2008; Wolf et al. 2013). In recent years, natural and constructed wetlands have been successfully implemented with the objective of retaining $\mathrm{P}$ in agricultural landscapes (Kröger et al. 2013).

Plankton exerts a key role in lotic ecosystems, since that biota represents a food supply for many consumers and a quality source of organic carbon. The structure and dynamics of the phytoplankton and zooplankton communities are believed to be largely controlled by physicochemical conditions such as temperature, photoperiod, turbulence, water velocity, and turbidity (Thorp et al. 1994; Basú and Pick 1996). In addition, the geomorphological features of the river basin and the ongoing hydrologic condition may also regulate plankton growth and development (de Ruyter van Steveninck et al. 1992; Descy and Gosselain 1994). As a consequence, chlorococcal chlorophytes, diatoms, rotifers, and small cladocerans are frequently the dominant groups of the river plankton because of their particular adaptations to those physical limitations (Reynolds and Descy 1996). Moreover, plankton is considered as a resilient community owing to that biota's special 
characteristics such as microscopic dimensions, quick growth, short life cycles, and the production of resting eggs and other resistant structures that enable the organisms to cope with disturbances (Fisher et al. 1998; Rossetti et al., 2009).

The study area-located in the northwestern portion of the Salado-River basin (Buenos Aires, Argentina)is generally known as the sandy pampa (or western pampa) because of the characteristic landscape of longitudinal and parabolic dunes of sand previously formed by eolian accumulations during the present Holocene epoch (Imbellone and Giménez 1998; Viglizzo and Frank 2006). The natural drainage network of the Salado River is poorly developed and lacks hydrologic integration (Carol et al. 2010). In particular, the sandy pampa - an endorheic zone covering $66,000 \mathrm{~km}^{2}$ - is drained artificially by urban and rural canals that constitute a complex network. These canalizations were constructed and connected within the Salado basin in the last decades, after the extreme floodings registered during 1987 through 1988 (Ludueña 2006). Since then, large amounts of salts have been mobilized from the saline groundwater of the northwest region to be discharged into the Salado River, thus promoting an increased salinization.

The consequences of secondary salinization in streams and rivers have been largely studied in the USA, Europe, and Australia (Cañedo-Argüelles et al. 2013; Kefford et al. 2016). In this regard, research efforts are needed in the Salado-River basin, since that watershed is one of the most productive agricultural and cattle breeding regions in the country (González and Fernández 2007). Previous studies had recognized the chemical characteristics and the nutrient dynamics of the Salado River as well as the influence of the hydrologic regime on plankton development (Neschuk 2001; Gabellone et al. 2005, 2013a, b; Bazzuri et al. 2008, 2010). Those investigations, however, were not focused on the main affluents of the upper stretch of the basinthat is, the saline canalizations of the sandy pampa. Those water discharges, being mainly governed by the ongoing hydrologic condition, affect the water characteristics of the Salado-River water. In addition, the canalizations pass through diverse wetlands and shallow lakes within the study area. Hence, the characteristics of the water of those canals are modified by this serial system of lentic environments, which effluents subsequently drain towards the Salado River. On the basis of these considerations, the objectives of this work were (a) to measure the physicochemical characteristics of the water in the drainage canals; (b) to assess the effect of the drained wetlands and shallow lakes present within the study area on the water from the canals; (c) to examine the influence of the canals' allochthonous discharges on the Salado River's main course; (d) to analyze the structure, dynamic, and richness of the plankton community in the study area and; (e) to recognize the changes in the system under different hydrologic conditions (i. e., flooding, mean flows, drought).

\section{Materials and methods}

\section{Study area}

The Salado - the southernmost tributary of the La Plata River estuary and $571 \mathrm{~km}$ in length - is a typical lowland river with a gentle slope $\left(0.107 \mathrm{~m} \mathrm{~km}^{-1}\right)$ whose catchment covers $150,000 \mathrm{~km}^{2}$ in the pampas plain (Bazzuri et al. 2010). Because of these geomorphologic characteristics, evaporation and infiltration became predominant (Forte Lay et al. 2007). In addition, a regional climatic phenomenon consisting of interannual hydrologic cycles occurs, where various consecutive wet years are followed by dry ones in an irregular pattern (Iriondo and Kröhling 2007). The alternation between extended periods of excessive and deficient precipitations produces prolonged floodings and droughts that greatly affect human activities in the region (Scarpati et al. 2002; Cesanelli and Guarracino 2011). More information about the geologic features and land use of the Salado basin can be found in Gabellone et al. (2005, 2008 and 2013a) and Neschuk (2001).

In the sandy pampa, the mean annual precipitation is $850 \mathrm{~mm}$ and the mean annual potential evapotranspiration $1092 \mathrm{~mm}$. Thus, a negative water balance is usually observed from November through February. During dry periods, the water tables drop and the water accumulated in land depressions evaporates producing soil salinization (Badano 2010). This process threatens the economic exploitation of the land; it is mainly devoted to extensive cattle breeding along with crop and pasture rotation (Ghersa et al. 2002; Viglizzo and Frank 2006).

A characteristic feature of the sandy pampa is the close linkage between ground- and surface-water processes-namely, the occurrence of groundwaterinduced surface flooding and runoff (Palmer et al. 
2002). The chemical characteristics of the groundwater in the study area are only partially known. For its part, the sandy-pampa region has saline groundwater with moderate conductivity values and chloride-sodic waters. These chemical characteristics result from the presence of continental evaporites, widely distributed in this endorheic region and in the Salado-River basin. In addition, the aquifer also flows through subterranean gypsum deposits, thus contributing sulfates (Aradas et al. 2002; Kruse and Zimmermann 2002; Rojo et al. 2006). In contrast, the city of Bragado lies above a freshwater aquifer that supplies water to the surroundings. Although the proportion of the precipitation and groundwater supplying the river discharge is still unknown, the ionic composition of the river's water within the stretch under investigation suggests that the groundwater is the main input (Gabellone et al. 2008).

\section{Sampling stations}

The sampling stations were chosen in order to include (i) the transport of the water that comes from the sandy-pampas region via the canals, (ii) that water's passage through the main shallow lakes and wetlands of the study area, and (iii) the influence of those discharges into the Salado River. For this purpose, the following sampling stations were selected: the Mercante Canal (C1), where all the sandy-pampa canalizations converge; the Vinculación Canal (C2), which channel links the wetland between the Municipal and the Bragado shallow lakes; the Este Canal (C3); and the
Saladillo Stream (S) - the latter two being effluents from the Bragado shallow lake and discharge into the Salado River. In the river, we placed an upstream (R1) and a downstream (R2) site in relation to the discharge of the aforementioned system of tributary canals. The study area covered ca. $3000 \mathrm{~km}^{2}$ (Fig. 1). Samples were taken under four different hydrologic conditions, heretofore referred to as: A, high water (flooding; May 2007); B, mean flows (March 2008); C, low flows (drought; November 2008); and $\mathrm{D}$, very low flows (extreme drought) in the tributaries but with mean flows in the river proper (September 2009). The Este Canal Station was added and then sampled during low-water conditions (C and D). The total annual precipitation at Bragado city was $1015 \mathrm{~mm}$ in 2007, $734 \mathrm{~mm}$ in 2008 , and $926 \mathrm{~mm}$ in 2009, occurring mostly in spring and autumn (SMN 2016).

\section{Analytical procedures}

At each sampling site, the temperature, turbidity, $\mathrm{pH}$, and conductivity were measured with a multiple sensor Horiba U-10; dissolved-oxygen concentration (DO) with YSI oximeter; and light penetration with a Secchi disk. Because no flow-discharge data were available for the study area, we measured the flow velocity by means of a current meter and determined the hydrometric level as well. A submersible centrifugal pump was used for sample extraction from the center of the channel. Samples were collected in 1-L acidcleaned polyethylene bottles for chemical analysis. For in situ chlorophyll- $a$ estimates, water samples were drawn

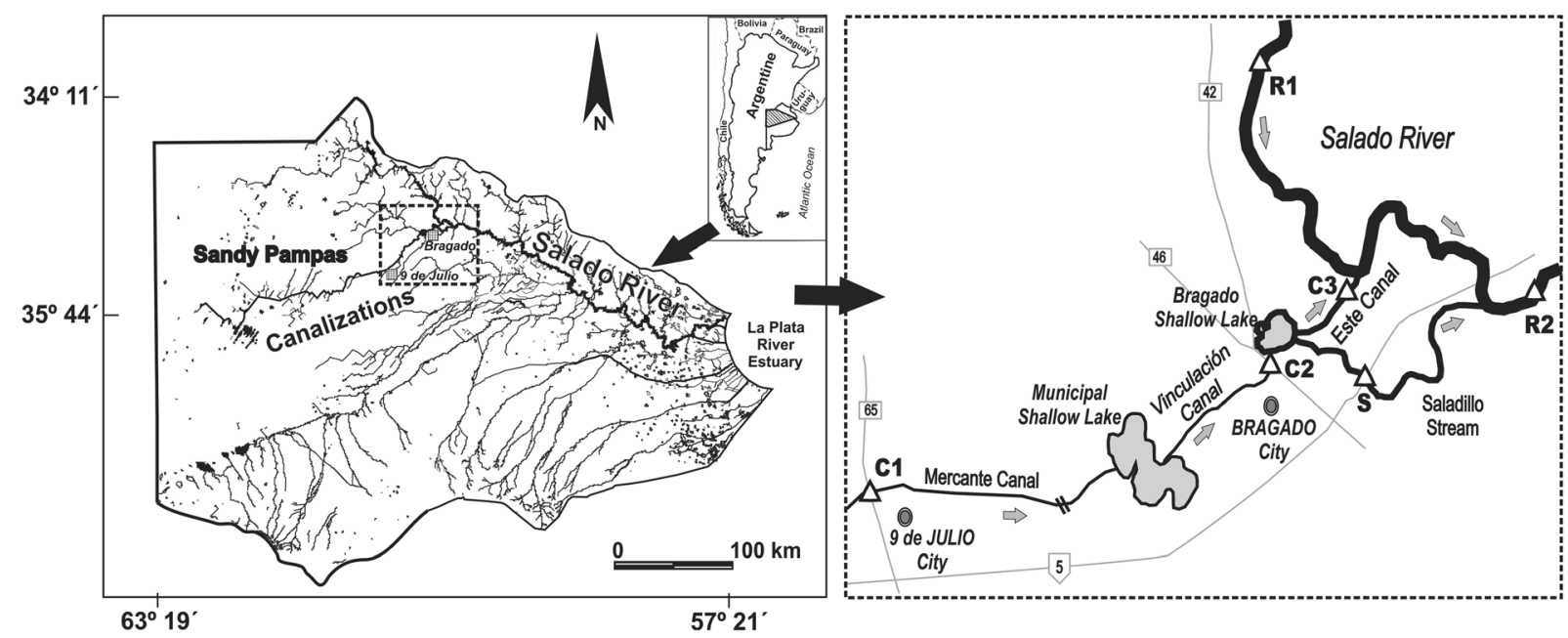

Fig. 1 Site map of the Salado-River watershed (left panel), showing the recent channelizations within the sandy pampas, the location of the study area (dotted box, enlarged in the right panel), and

a schematic drawing (right panel) depicting the positioning of the sampling stations (triangles) 
through Whatman GF/C filters into a suction flask connected to a manual vacuum pump. Phytoplankton samples were preserved in $1 \%$ acetic Lugol's solution and stored at room temperature until the time of analysis. Avolume of $50 \mathrm{~L}$ was pumped from a depth of $0.5 \mathrm{~m}$ below the surface and passed through a $25-\mathrm{mm}$-diameter hose into a $35-\mu \mathrm{m}$ mesh net. The material retained was preserved in a $4 \%$ aqueous formaldehyde solution. All samples were transported to the laboratory in an ice-cooled isolation box and thereafter stored in the dark at $5-8{ }^{\circ} \mathrm{C}$ until further analysis.

In the laboratory, $\mathrm{Na}^{+}$and $\mathrm{K}^{+}$concentrations were determined according to method $3500 \mathrm{D}$ (APHA 1995) and $\mathrm{Cl}^{-}$by argentometry, $\mathrm{SO}_{4}{ }^{2-}$ turbidimetrically in a spectrophotometer, $\mathrm{Ca}^{2+}$ concentration by EDTA titrimetry, and $\mathrm{Mg}^{2+}$ by subtraction from the total carbonate content. The total alkalinity was determined by sulfuric acid $(0.02 \mathrm{~N})$ titration, and $\mathrm{HCO}_{3}{ }^{-}$and $\mathrm{CO}_{3}{ }^{2-}$ estimated on the basis of stoichiometric relationships. $\mathrm{N}-\mathrm{NO}_{3}{ }^{-}$plus $\mathrm{N}-\mathrm{NO}_{2}{ }^{-}(\mathrm{N}+\mathrm{N})$ and $\mathrm{N}-\mathrm{NH}_{4}{ }^{+}$were assayed by the $4500-\mathrm{H}$ and $4500-\mathrm{F}$ methods, respectively (APHA 1995). Total nitrogen (TN) was estimated by spectrophotometry at $220 \mathrm{~nm}$ after acidic-persulfate digestion and autoclaving at $1 \mathrm{~atm}$ pressure (Tartari and Mosello 1997). Dissolved reactive phosphorus (DRP) and total reactive phosphorus (TRP) were determined by the $4500-(\mathrm{P})-\mathrm{E}$ method. The same methodology was used for total phosphorus (TP) and total dissolved phosphorus (TDP) after digestion with acidic persulfate (APHA 1995). The naming of these phosphorus fractions is after that used by Gabellone et al. (2013a). The total suspended solids (SS) and particulate organic matter (OM) were measured according to the $2540 \mathrm{D}$ method. The dissolved organic matter (DOM) was estimated indirectly by spectrophotometry at $440 \mathrm{~nm}$ (Kirk 1983), and the dissolved polyphenols by the $5550 \mathrm{~b}$ method (APHA 1995). The chlorophyll- $a$ concentration was determined spectrophotometrically after extraction with 90\% $(w / v)$ aqueous acetone (10200-H method) after correction for pheopigments (Wetzel and Likens 1991).

The phytoplankton counts were made with $5-\mathrm{mL}$ sedimentation chambers under the inverted microscope (at $\times 400$ ) according to the method of Utermöhl. In each sample, random fields were counted up to a minimum of 400 settling units (i. e., cells, colonies, filaments) at a counting precision of $\pm 10 \%$ for the total phytoplankton (Padisák and G.-Tóth 1991). The algal biovolumes $\left(\mathrm{mm}^{3} \mathrm{~L}^{-1}\right)$ were calculated after adjusting the geometrical figures (Hillebrand et al. 1999; Sun and Liu 2003) and then transformed to carbon (Menden-Deuer and Lessard 2000).
The protozoans and rotifers were counted in (1-mL) Sedgewick-Rafter chambers under a binocular microscope and the crustaceans in (10-mL) Bogorov chambers under a stereomicroscope. After sample mixing with a magnetic stirrer, repeated subsamples were counted. The zooplankton biomass was calculated after the formulas of Dumont et al. (1975), Bottrell et al. (1976), and Karayanni et al. (2004) and then dry weight and carbon transformed (Mc-Cauley 1984; Lawrence et al. 1987; Putt and Stoeckner 1989; Andersen and Hessen 1991). Replicate samples of phytoplankton and zooplankton were counted until a coefficient in variation $<20 \%$ in the total abundance of the dominant species was reached. The mean values were then used in the subsequent analyses. The planktonic organisms were identified down to the lowest possible taxonomic level.

\section{Statistical determinations}

Multidimensional-scaling analysis (MDS) was employed in order to analyze the ionic composition by means of a similarity matrix (Euclidean distance, complete linkage), based on previously normalized data. In addition, a significant cluster analysis was done with a 999 simulations. A principal-component analysis (PCA) was carried out in order to determine relationships among the environmental variables and sampling sites under each hydrologic condition, and a $k$-means analysis was performed by taking into account the results from all four surveys and applying the Euclidean distance and completeness of linkage to a basic matrix of physicochemical-parameter data. Finally, the phytoplankton- and zooplankton species composition was analyzed by means of a Bray-Curtis likelihood index with a significant test based on 900 simulations.

\section{Results}

Table 1 presents the range of values of the main physicochemical variables measured at each sampling site. The water of the Salado River and its tributaries was alkaline and mainly chloride-sodic according to Piper diagrams, with slight variations depending on the sampling site and the hydrologic condition (Fig. 2). The concentrations of the principal cations were generally in the order of $\mathrm{Na}^{+}>$ $\mathrm{Mg}^{2+}>\mathrm{Ca}^{2+}>\mathrm{K}^{+}$, except for site $\mathrm{C} 3$ in very low flows, where $\mathrm{Mg}^{2+}$ became the dominant cation. The anion concentrations followed the order $\mathrm{Cl}^{-}>\mathrm{HCO}_{3}{ }^{-}>\mathrm{SO}_{4}{ }^{2-}$ in high water (flooding), and the order $\mathrm{Cl}^{-}>\mathrm{SO}_{4}{ }^{2-}>$ 
Table 1 Range of maximum and minimum values of the physicochemical variables recorded at each sampling site during the four surveys (i. e., high water, mean flows, drought, and extreme drought)

\begin{tabular}{|c|c|c|c|c|c|c|}
\hline Variables/sites & $\mathrm{C} 1$ & $\mathrm{C} 2$ & $\mathrm{C} 3$ & S & $\mathrm{R} 1$ & $\mathrm{R} 2$ \\
\hline Water temperature $\left({ }^{\circ} \mathrm{C}\right)$ & $11.4-29.7$ & $9-31.5$ & $11.6-29$ & $15.7-25.8$ & $9.8-27$ & $9.9-33.2$ \\
\hline Conductivity $\left(\mathrm{mS} \mathrm{cm}^{-1}\right)$ & $10.2-25$ & $4.1-19.3$ & $2.7-16.8$ & $1.03-16.9$ & $3.8-14.4$ & $3.7-6$ \\
\hline Salinity (PSU) & $0.56-1.54$ & $0.2-1.14$ & $0.13-0.99$ & $0.04-1$ & $0.18-0.81$ & $0.18-0.31$ \\
\hline $\mathrm{pH}$ & $8.3-8.9$ & $8.5-9.3$ & $8.1-8.7$ & $8.7-9.3$ & $8.4-9.2$ & $8.6-9.4$ \\
\hline Turbidity (NTU) & $85-234$ & $70-273$ & $52-200$ & $47.9-223$ & $44-361$ & $42-694$ \\
\hline Dissolved-oxygen concentration $\left(\mathrm{mg} \mathrm{L}^{-1}\right.$ ) & $5-18$ & $5.6-14.4$ & $2.6-17$ & $6.3-12$ & $7-18.4$ & $6-17.1$ \\
\hline Secchi disk $(\mathrm{cm})$ & $24-52$ & $18-35$ & $13.5-40$ & $26-60$ & $16-65$ & $7-37$ \\
\hline Flow velocity $\left(\mathrm{m} \mathrm{s}^{-1}\right)$ & $0.001-0.73$ & $0.001-1.09$ & $0.001-0.17$ & $0.006-0.04$ & $0.139-1.67$ & $0.08-0.82$ \\
\hline Total suspended solids $\left(\mathrm{mg} \mathrm{L}^{-1}\right)$ & 43-207 & 43-196 & $34-102$ & $15-103$ & $23-203$ & $32.4-402$ \\
\hline Particulate organic matter $\left(\mathrm{mg} \mathrm{L}^{-1}\right)$ & $14.2-91$ & $22.7-98.7$ & $14-47$ & $10-44.9$ & $14.3-92$ & $18-164$ \\
\hline Dissolved organic matter (absorbance at $440 \mathrm{~nm}$ ) & $0.012-0.23$ & $0.015-0.18$ & $0.043-0.14$ & $0.003-0.17$ & $0.036-0.33$ & $0.037-0.74$ \\
\hline Dissolved polyphenols (mg L ${ }^{-1}$ ) & $0.6-3.7$ & $0.95-3.25$ & $0.92-2.5$ & $0.31-0.92$ & $0.92-2.5$ & $1.1-1.98$ \\
\hline Alkalinity $\left(\mathrm{mg} \mathrm{L}^{-1}\right)$ & $320-1019$ & $333-524$ & $389-581$ & $230-574$ & $419-614$ & $445-785$ \\
\hline Hardness $\left(\mathrm{mg} \mathrm{L}^{-1}\right)$ & $1700-4600$ & $1060-2950$ & $1100-2950$ & $1400-2800$ & $840-3300$ & $900-2300$ \\
\hline $\mathrm{N}-\mathrm{NO}_{2}^{-}\left(\mu \mathrm{g} \mathrm{L}^{-1}\right)$ & $1.8-228$ & $1.2-39$ & $8.25-152$ & $8.6-57.9$ & 4-45.5 & $3.7-52$ \\
\hline $\mathrm{N}-\mathrm{NO}_{3}^{-}\left(\mu \mathrm{g} \mathrm{L}^{-1}\right)$ & $7.4-161$ & $3.6-106$ & $34.5-730$ & $79.4-153$ & $10.6-273$ & $15-262$ \\
\hline $\mathrm{N}-\mathrm{NH}_{4}^{+}\left(\mu \mathrm{g} \mathrm{L}^{-1}\right)$ & $0.7-1334$ & $6.1-114$ & $1382-8883$ & $0.68-12.4$ & $10.5-130$ & $5.4-185$ \\
\hline Total nitrogen $\left(\mu \mathrm{g} \mathrm{L}^{-1}\right)$ & $2300-5976$ & $3430-7132$ & $4550-13,500$ & $1580-3780$ & $3890-6799$ & $5540-10,150$ \\
\hline Total dissolved nitrogen $\left(\mu \mathrm{g} \mathrm{L}^{-1}\right)$ & $1850-3076$ & $1090-4095$ & $2870-11,460$ & $930-2170$ & $1660-3350$ & $1810-3997$ \\
\hline Total particulate nitrogen $\left(\mu \mathrm{g} \mathrm{L}^{-1}\right)$ & $400-3174$ & $1470-3880$ & $860-3977$ & $650-1610$ & $2230-4134$ & $2950-6153$ \\
\hline Total reactive phosphorus $\left(\mu \mathrm{g} \mathrm{L}^{-1}\right)$ & $68-282$ & $52-444$ & $285-988$ & $35-125$ & $174-1010$ & $554-1418$ \\
\hline Dissolved reactive phosphorus $\left(\mu \mathrm{g} \mathrm{L}^{-1}\right)$ & $28-137$ & $24.4-377$ & $250-1465$ & $11.6-92$ & $130-909$ & $332-1389$ \\
\hline Particulate reactive phosphorus $\left(\mu \mathrm{g} \mathrm{L}^{-1}\right.$ ) & $12.8-206$ & $9.1-144$ & $28.2-160$ & $20-32.8$ & $180-16.4$ & $29-222$ \\
\hline Total phosphorus $\left(\mu \mathrm{g} \mathrm{L}^{-1}\right)$ & $507-1363$ & $463-1142$ & $916-3763$ & $334-597$ & $637-1740$ & $903-3767$ \\
\hline Total dissolved phosphorus $\left(\mu \mathrm{g} \mathrm{L}^{-1}\right)$ & $136-774$ & $197-620$ & 489-2419 & $74-183$ & $291-1111$ & $546-2086$ \\
\hline Total particulate phosphorus $\left(\mu \mathrm{g} \mathrm{L}^{-1}\right)$ & $209-589$ & $159-610$ & $202-1343$ & $173-413$ & $97-1146$ & $186-1747$ \\
\hline $\mathrm{N}: \mathrm{P}$ ratio & $4.2-10$ & $4.7-7.5$ & $3.3-5.4$ & $3.9-6.3$ & $2.65-6.44$ & $1.84-6.09$ \\
\hline Chlorophyll $a\left(\mathrm{mg} \mathrm{m}^{-3}\right)$ & $15-322$ & $50.7-247$ & $33.7-141$ & $28.7-141$ & $20.4-370$ & $30.4-416$ \\
\hline
\end{tabular}

$\mathrm{HCO}_{3}{ }^{-}$in mean and low flows (drought). Both orders were observed during the last survey (i. e., extreme drought in the canals), depending on sampling site.

The conductivity was either high or very high at $\mathrm{C} 1$, reaching a maximum value in low flows. From the highest of those readings, the conductivity decreased at $\mathrm{C} 2, \mathrm{C} 3$, and S; registering very high, high, or low values depending on the hydrologic circumstance. In the river, the conductivity was moderate at R1 but was higher at R2 under all four hydrologic conditions. Minimum conductivity values were reached during floodings, except at $\mathrm{C} 3$ and $\mathrm{S}$, which sites had oligohaline water (Fig. 3).

During flooding, the values of SS, OM, and turbidity of the water reached maxima in $\mathrm{C} 1$, and then diminished throughout the canals up to the water's discharge into the river. In the mean-flow and low-water periods, these parameters registered maximum values in R1, while R2 presented conditions similar to those of the canals. Minimum values were recorded in the tributaries during the extreme drought. Water transparency exhibited an opposite pattern.

The river sites registered more highly oxygenated water than did those of the tributaries. Minimal DO values were observed in $\mathrm{S}$ along with peak concentrations of $\mathrm{N}$ and $\mathrm{P}$ nutrients, particularly the dissolved forms $(75-93 \%)-i$. e., $\mathrm{N}-\mathrm{NH}_{4}{ }^{+}, \mathrm{N}+\mathrm{N}, \mathrm{TN}, \mathrm{TDN}$, DRP, TP, and TDP. In spite of the input from these tributaries, the nutrient concentrations diminished at the 

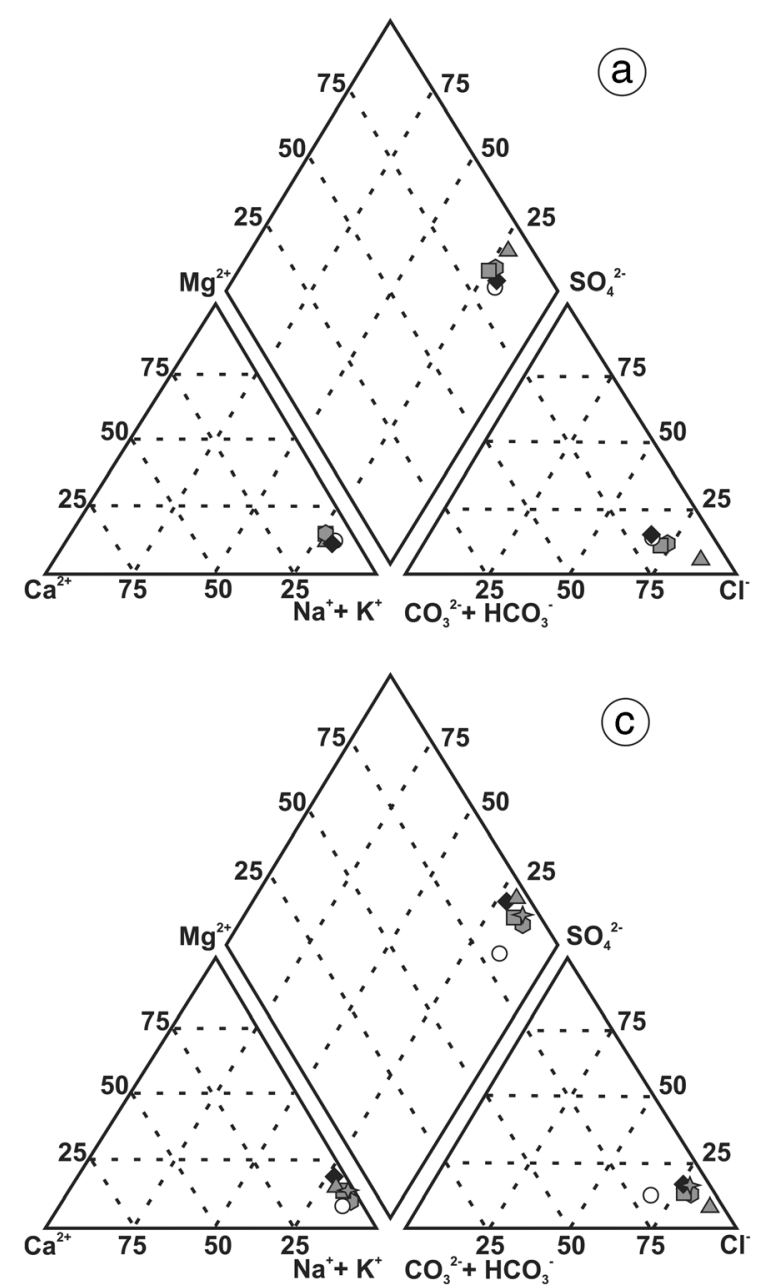

Fig. 2 Piper diagrams for each sampling condition: a high water (flooding); b mean flows; c low flows (drought); d very low flows (extreme drought) in the tributaries with mean flows at the Salado-

river downstream site (R2), except for ammonium on the last sampling occasion (i. e., mean-flow). The TDP concentrations were only substantial in high waters, while the PP became appreciable mostly in the low and very low flows. The DRP was the dominant $\mathrm{P}$ fraction at all sites and under all hydrologic conditions, representing from 3 to $42 \%$ of the TP at the canal sites, and $61 \%$ at the river sites while reaching up to $64 \%$ at site $\mathrm{S}$.

The N:P ratio exhibited a wider range of values in the tributary system, particularly at $\mathrm{C} 1$; decreasing in amplitude at $\mathrm{C} 2$ and $\mathrm{C} 3$, exhibiting a minimum range of values at $\mathrm{S}$ between surveys. At the downstream sampling site of the river (R2), an increase in this ratio was observed, having values similar to $\mathrm{C} 2$.

The dissolved polyphenols reached maximum values during flooding, particularly at $\mathrm{C} 1$ (at $3.5 \mathrm{mg} \mathrm{L}^{-1}$ ), and
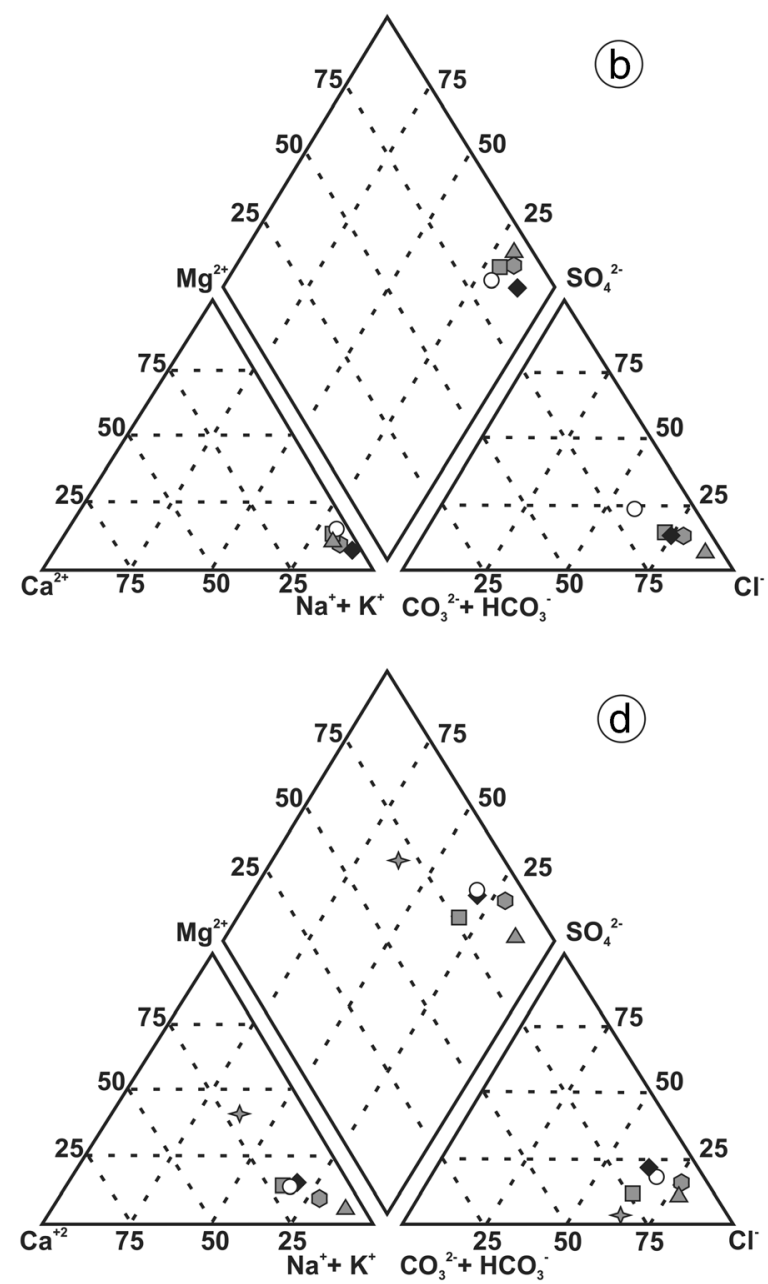

River sampling sites. Key to symbols: C1 (gray triangle), C2 (gray hexagon), C3 (gray star), S (gray square), R1 (white circle), and R2 (black diamond)

exhibited a gradient in concentration along the tributary system. In very low flows, an opposite pattern was observed that coincided with especially low concentrations of DOM.

The chlorophyll- $a$ and total plankton-biomass values underwent a seasonal development, with the phytoplankton and zooplankton biomasses attaining peak levels during mean flows and the low flows coinciding with the spring-summer favorable period. Apart from the seasons, during floodings, mean flows, and droughts a progressive decrease was observed along the tributary system, from higher values at $\mathrm{C} 1$ to gradually lower values at the $\mathrm{C} 2$, the $\mathrm{C} 3$, and finally the $\mathrm{S}$ sampling sites. The highest chlorophyll- $a$ values were registered at the Salado-River upstream site (R1), particularly during mean flows. In addition, the highest total 


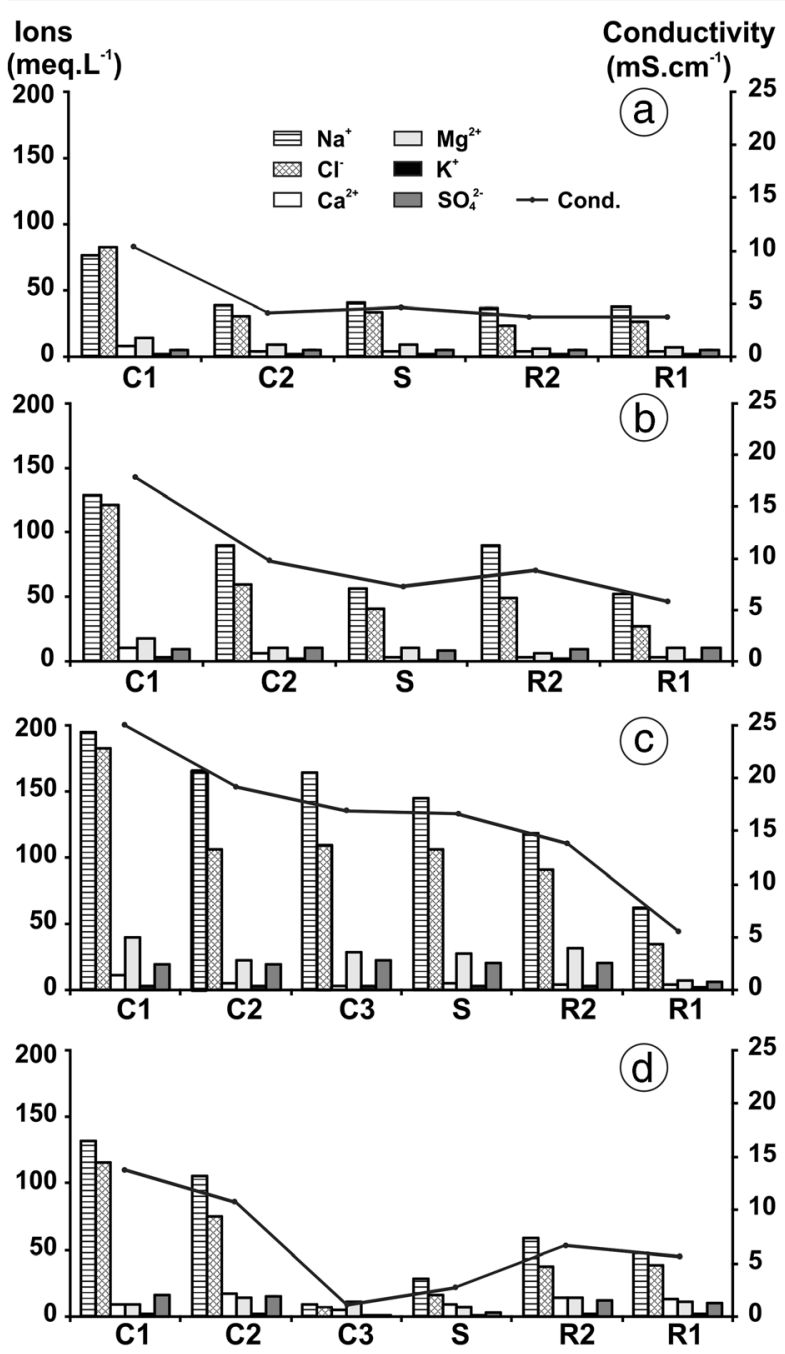

Fig. 3 Physicochemical variables at each sampling site and under each hydrologic condition: panels a high water (flooding); panels b mean flows; panels c low flows (drought); panels d very low flows (extreme drought) in the tributaries $(\mathrm{C} 1, \mathrm{C} 2, \mathrm{C} 3, \mathrm{~S})$ with mean flows throughout the Salado-River (R1, R2). Left column:

phytoplankton-biomass value was registered at the $\mathrm{C} 1$ site, the most distal from the river. The zooplankton biomass was higher at sites $\mathrm{C} 1$ and $\mathrm{C} 2$ in the canals than in the river sites, with a considerable peak at $\mathrm{C} 2$ during low flows; whereas an increase in the total plankton biomass occurred at the river downstream sampling site (R2) during all three hydrologic conditions - high-water, mean flows, and drought (Fig. 4).

A total of 438 taxa of phytoplankton and 166 taxa of zooplankton were identified during the study. The Chlorophyceae and Bacillariophyta (i. e., the diatoms) were the most notable groups of the phytoplankton (140 taxa each), followed by the Cyanobacteria (90 taxa). In

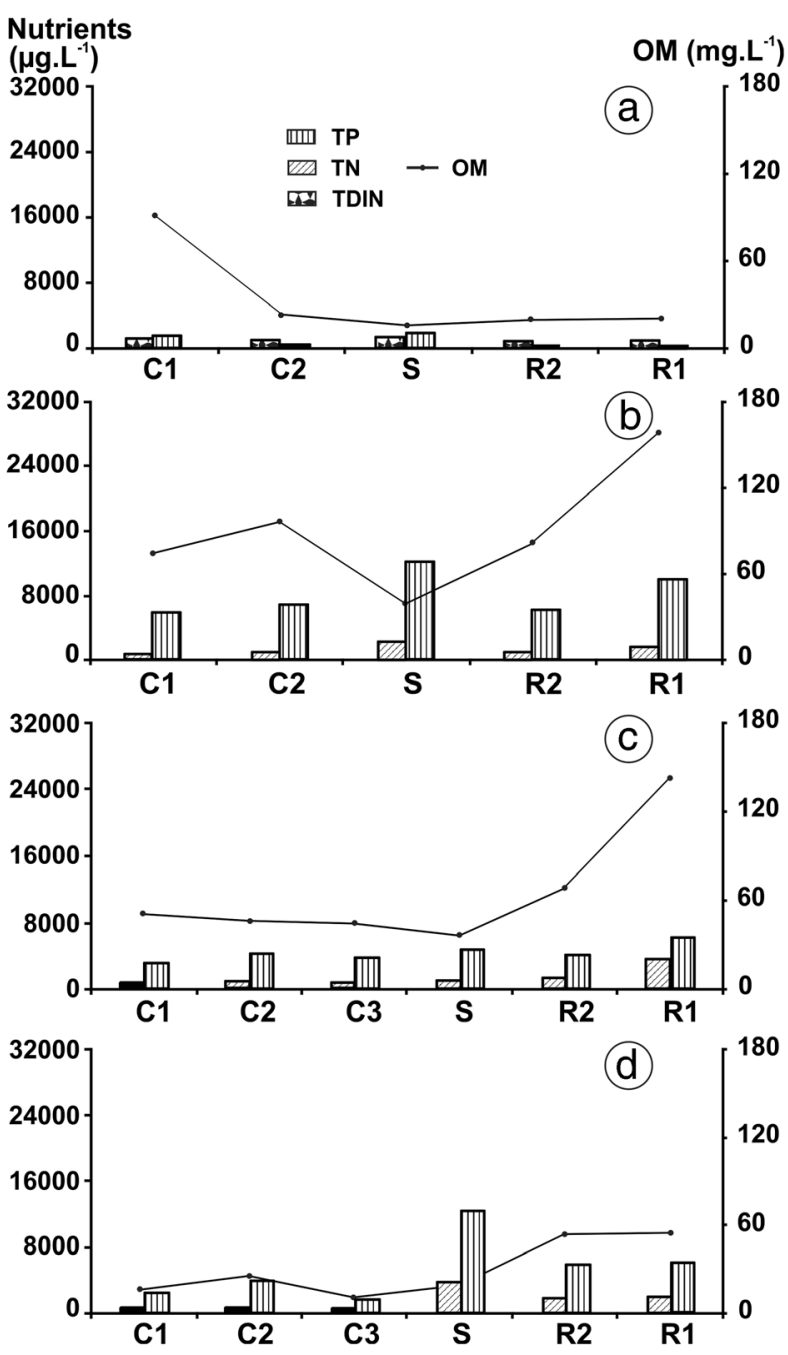

Conductivity values (Cond.) in $\mathrm{mS} \mathrm{cm} \mathrm{c}^{-1}$ (right ordinate) and ion concentrations in meq $\mathrm{L}^{-1}$ (left ordinate and bars). Right column: $\mathrm{OM}$ values in mg. $\mathrm{L}^{-1}$ (right ordinate) and concentration in $\mu \mathrm{g} . \mathrm{L}^{-1}$ (left ordinate and bars) of TP and TN. N. b.: in right panel a, instead of TN, total dissolved inorganic nitrogen (TDIN) is plotted

addition, the Euglenophyta comprised some 45 taxa, but the Cryptophyta (13 taxa) and the Dinoflagellata (8 taxa) were of lesser relevance. Among the zooplankton, the Rotifera were the richest group (93 taxa), followed by the Ciliophora (45 taxa). In contrast, among the less rich groups, the Cladocera contained 9 taxa, the Copepoda 9 , the Rhizopoda 6, and the Ostracoda 2. Variations in the phytoplankton- and zooplankton species composition were observed with respect to the sampling sites and to the hydrologic conditions (Fig. 5).

According to the MDS analysis, the sites were grouped mostly with respect to the ongoing hydrologic condition (Fig. 6). In low flows (drought), the C2, C3, S, and R2 sites 
Fig. 4 Total phytoplankton (right ordinate and bars) and zooplankton (left ordinate and line) biomass ( $\left.\mu \mathrm{g} \mathrm{C} \mathrm{L}^{-1}\right)$ at each sampling site and under each hydrologic condition: panel a high-water; panel b mean flows; panel c low flows (drought); panel d very low flows (extreme drought) in the tributaries ( $\mathrm{C} 1$, $\mathrm{C} 2, \mathrm{C} 3, \mathrm{~S}$ ) with mean flows throughout the Salado-River (R1, $\mathrm{R} 2$ ). In the panels, the biomass in $\mu \mathrm{g} \mathrm{C} \mathrm{L}{ }^{-1}$ is plotted on the ordinate for each of the sampling sites indicated on the abscissa. N. $b$.: because the phytoplankton value (gray bar) at site C1 of panel b was above the maximum ordinate value, the bar is left open and the exact biomass denoted above
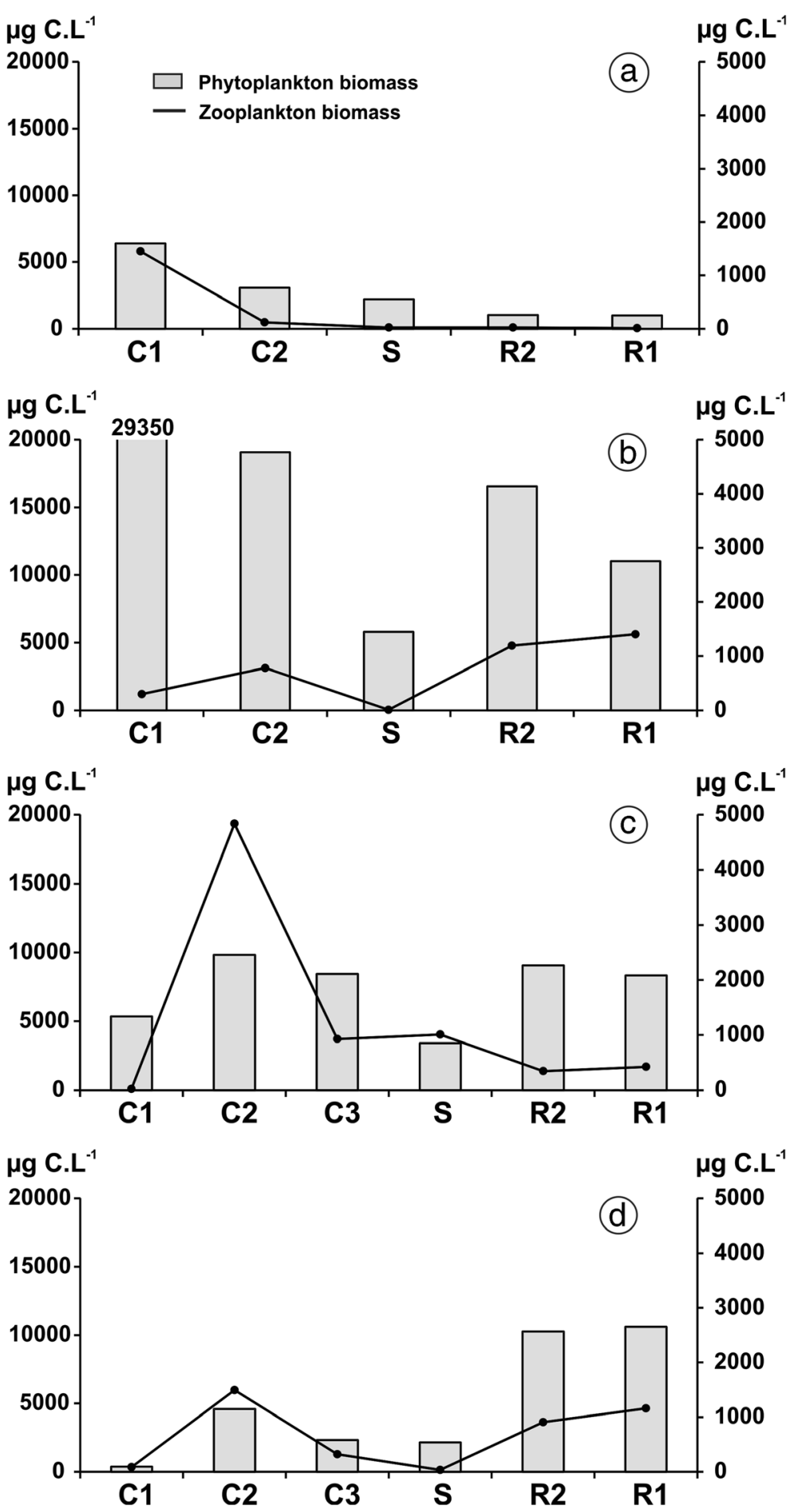

were grouped according to $\mathrm{Mg}^{2+}$ and $\mathrm{SO}_{4}{ }^{2-}$ concentrations; but the river upstream site (R1) was closely related to itself during the different sampling occurrences. Sites were arranged according to $\mathrm{Ca}^{2+}$ concentrations during the hydrologic condition of very low flows in the tributaries and mean flows in the river. Site $\mathrm{C} 1$ was separated in the analysis from $\mathrm{Na}^{+}+\mathrm{K}^{+}$concentrations in low flows (drought) and from $\mathrm{Cl}^{-}$and $\mathrm{HCO}_{3}{ }^{2-}$ concentrations in 

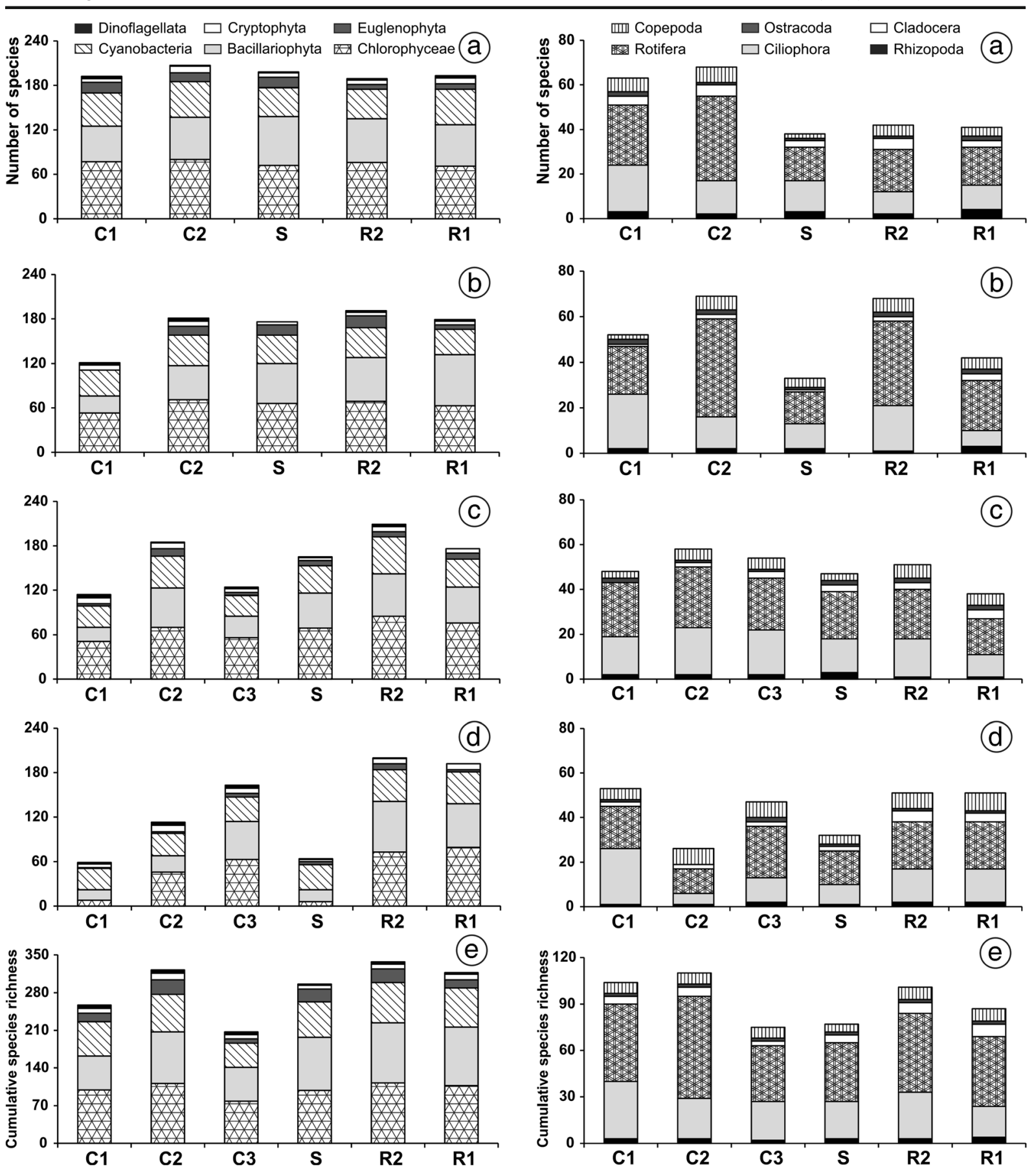

Fig. 5 Plankton-species richness at each sampling site and under each hydrologic condition: panel a high water (flooding); panel b mean flows; panel c low flows (drought); panel $\mathbf{d}$ very low flows (extreme drought); panel e total number of cumulative species, in the tributaries $(\mathrm{C} 1, \mathrm{C} 2, \mathrm{C} 3, \mathrm{~S})$ with mean flows throughout the

Salado-River (R1, R2). Left column, total number of phytoplankton species; Right column, total number of zooplankton species. The key to the bar textures representing the species is indicated above each column

very low flows (extreme drought). As a result, cluster $(p<0.05)$ at 13 nodes in the dendrogram, thus dividing analysis (Fig. 7) indicated significant differences the sampling sites into six main groups. A high-water 
Fig. 6 MDS analysis of the ionic composition of the water at each sampling site during the surveys: panel a high-water (white); panel b mean flows (light gray); panel c low flows (black); panel d very low flows in the tributaries but mean flows in the Salado River (darker gray). Key to symbols: C1, triangles; $\mathrm{C} 2$, hexagons; $\mathrm{C} 3$, stars; $\mathrm{S}$, squares; R1, circles; and R2, diamonds. The arrow indicates the close relationship between the R1 sites (circles) throughout the survey

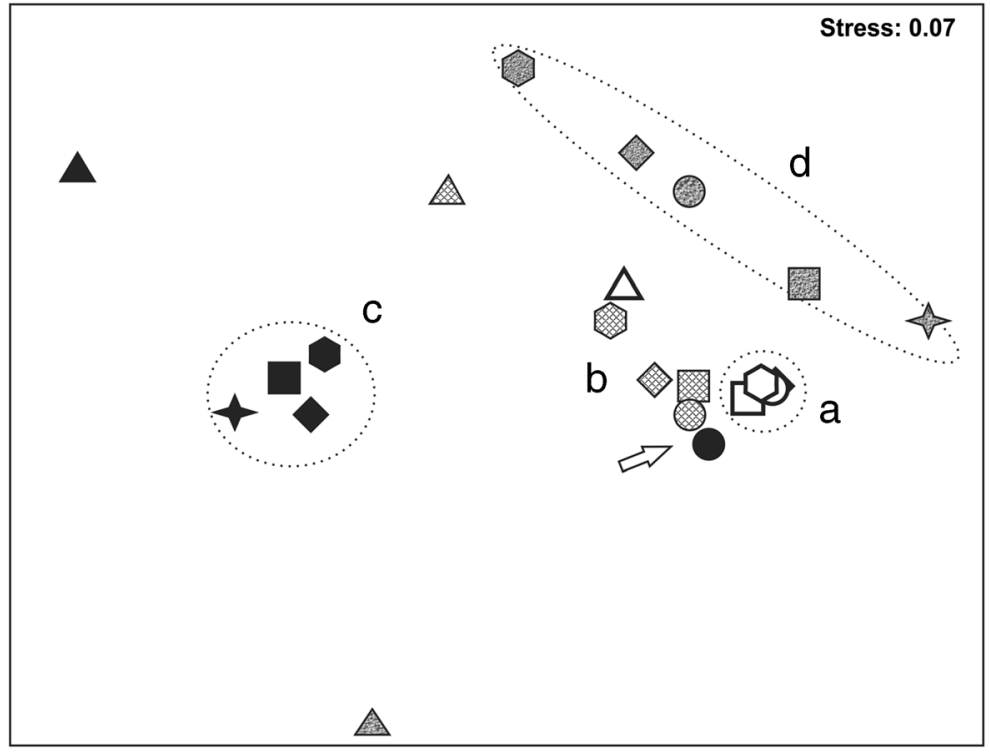

group had a minimal distance between sites, as did a lowwater group. The river downstream site (R2) was closely related to $\mathrm{C} 2$ in the mean-flow and low-water survey; whereas R1 remained significantly related to itself under different hydrologic conditions.

The PCA was suitable for the ordination of sampling sites under each hydrologic condition examined, explaining $79-88 \%$ of the total variation with respect to the first two axes (Fig. 8). Table 2 shows the correlations between the environmental variables and each axis (factors 1 and 2). Factor 3 was only considered in the last survey because of correlations $>0.8$. In this circumstance, the sum of the three factors explained up to $93 \%$ of the total variance.

Site $\mathrm{C} 1$ was characterized by high water conductivity and hardness under all hydrologic conditions, and by high values of turbidity, SS, OM, N + N, TP, TDP, and dissolved polyphenols during flooding. Site $\mathrm{S}$ featured elevated values of nutrients $\left(\mathrm{N}+\mathrm{N}, \mathrm{N}-\mathrm{NH}_{4}{ }^{+}, \mathrm{TP}\right.$, TDP, DRP), DOM, and alkalinity, but exhibited a negative correlation with DO, under all hydrologic conditions. The river upstream site (R1) was associated with more highly oxygenated water during high-water periods and to higher values of $\mathrm{pH}, \mathrm{OM}, \mathrm{SS}$, turbidity, and $\mathrm{P}$ nutrients under the other hydrologic conditions. In contrast, R2 was closely similar to C2 during floodings, mean flows, and droughts. Both of those river sites (R1 and R2), however, became mutually associated under the extreme drought condition within the tributaries prevailing during the last survey.
The sampling sites were arranged by $k$-means analysis into the five following groups: (I) all sites during flooding, (II) R2 and tributaries during mean and low flows, (III) $\mathrm{S}$ sites during low and very low flows, (IV) $\mathrm{R} 1$ sites under different hydrologic conditions with $\mathrm{R} 2$ at the last survey, and (V) the canals during the extreme drought. The environmental variables were also grouped as follows: (I) temperature, conductivity, and hardness; (II) N-derived nutrients; (III) DO and P-derived nutrients; (IV) transparency, flow velocity, dissolved polyphenols, and hydrometric distance; and $(\mathrm{V}) \mathrm{pH}$, turbidity, SS, OM, DOM, alkalinity, and chlorophyll $a$.

With respect to species richness, the Bray-Curtis analysis indicated significant differences $(p<0.05)$ at 10 nodes in the dendrogram of the phytoplankton composition and at 14 nodes in the zooplankton array (Fig. 9). In both dendrograms, the river sampling sites R1 and R2 had the highest plankton similarity during mean flows with scarce inflows from the tributaries (extreme drought). In addition, the high-water groups had quite similar species compositions, as did the lowwater groups.

\section{Discussion}

The high conductivity values registered and the dominance of the $\mathrm{Na}^{+}$and $\mathrm{Cl}^{-}$ions result from evaporation and the influx of saline groundwater (Tanco and Kruse 2001; Gabellone et al. 2008). The recent construction of 


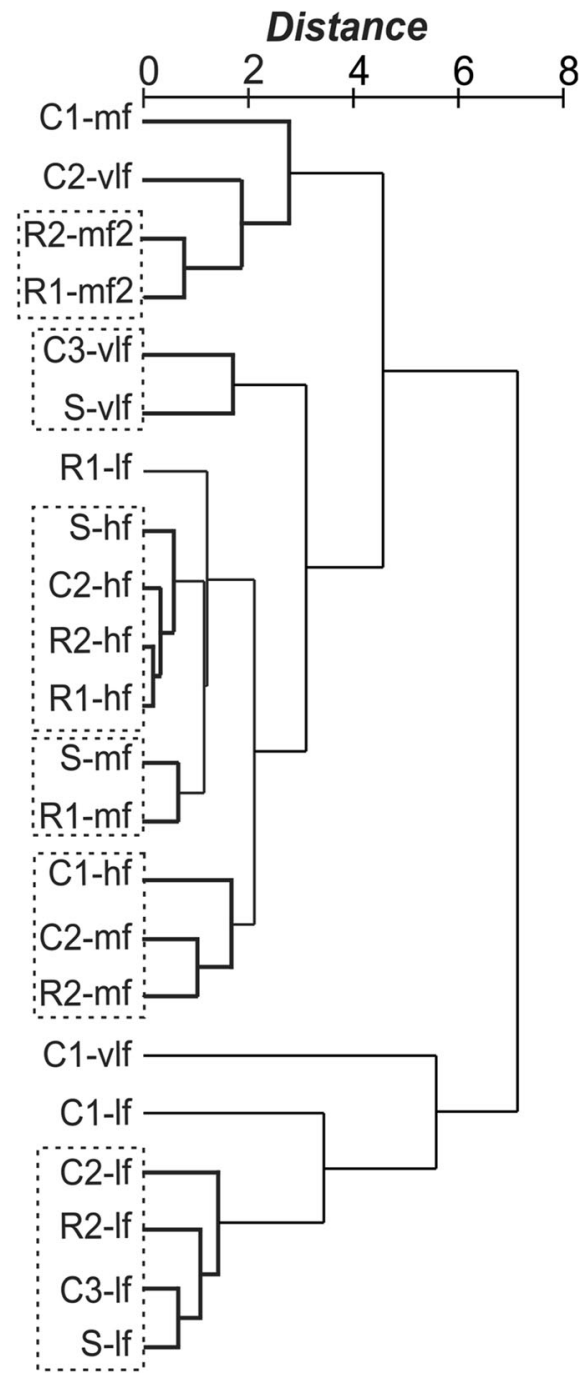

Fig. 7 Cluster analysis (Euclidean distance) of the water ionic composition at each sampling site during the surveys: high flows (hf), mean flows (mf), low flows (lf), very low flows (vlf) in the tributaries with mean flows $(\mathrm{mf} 2)$ in the river. The boldface denotes significant clades $(p<0.05)$

canalizations in the heretofore endorheic sandy pampa have worsened this situation. The ion concentration and conductivity of the water were mostly related to the hydrologic regime, with the lowest values occurring during flooding and the highest in low-flow periods (Neschuk 2001; de Cabo et al. 2003). This pattern also depended on the magnitude and duration of the flows and on the relative contribution of the groundwater, as in Australian hydrologic systems (Hart et al. 2003). The highest conductivity values registered for $\mathrm{C} 1$ (at 25 $\mathrm{mS} \mathrm{cm}{ }^{-1}$ ) are a novel occurrence for the Salado-River watershed.
The Piper diagrams indicated the $\mathrm{Na}-\mathrm{Cl}-\mathrm{HCO}_{3}$ water type to be found during high water, probably related to rain infiltration and carbonate dissolution from the bed rock. The rise in the water tables allowed the entry of fresh groundwater from the lenticular aquifers present inside the sand dunes and eolian mantles. The ionic composition of the water of these geologic formations results from $\mathrm{Ca}^{2+} / \mathrm{Na}^{+}$exchange and evaporation. As a result, the drainage canals also extract quality freshwater during the wet periods, which depletion constitutes a considerable constraint on the region (Rojo et al. 2006). Conversely, the $\mathrm{Na}-\mathrm{Cl}-\mathrm{SO}_{4}$ water type occurred during mean-flow and low-water periods, with that composition being characteristic of the water table beneath the Salado-River floodplains, where evaporation predominates (Kruse et al. 2010).

The oligohaline water $(0.04-0.13 \%$ ) observed at sites $\mathrm{S}$ and $\mathrm{C} 3$ during the extreme drought would indicate the occurrence of surface runoff along with the influx of fresh groundwater. A strong interaction between the surface running water and the groundwater can be inferred from the ionic composition of the water observed throughout the survey. Thus, the geomorphologic aspects of the Salado-River basin exert local constraints on this complex fluvial system (Kruse and Laurencena 2005; Carol et al. 2010); where the hydrologic regime, the river's discharge, and the basin's lithology represent the main influences that control the dynamics of the systems, as with other rivers worldwide (Meybeck 1996).

According to the multivariate analysis, the water of Site $\mathrm{C} 1$ was characterized by extremely high conductivity values, mostly owing to the presence of $\mathrm{Na}^{+}$and $\mathrm{Cl}^{-}$. Large amounts of those ions are located in the groundwater of the sandy-pampa endorheic region and derive from continental evaporites that originated in dry periods during the Pleistocene Epoch (Gabellone et al. 2005).

The conductivity and $\mathrm{Na}^{+}$plus $\mathrm{Cl}^{-}$values were higher at the Salado-River downstream site (R2) under all hydrologic conditions, as a result of the canal's discharge. This finding represents a relevant observation from the standpoint of the ongoing salinization that threatens the region. Increases in $\mathrm{Na}^{+}, \mathrm{Cl}^{-}$, and $\mathrm{SO}_{4}{ }^{2-}$ concentrations and the presence of powdery surface efflorescence represent another indication of the progressive salinization (Herczeg et al. 2001; Meybeck 2003) clearly observed in the watercourses analyzed. According to the multivariate procedures, the river's downstream site was significantly related to the tributary 

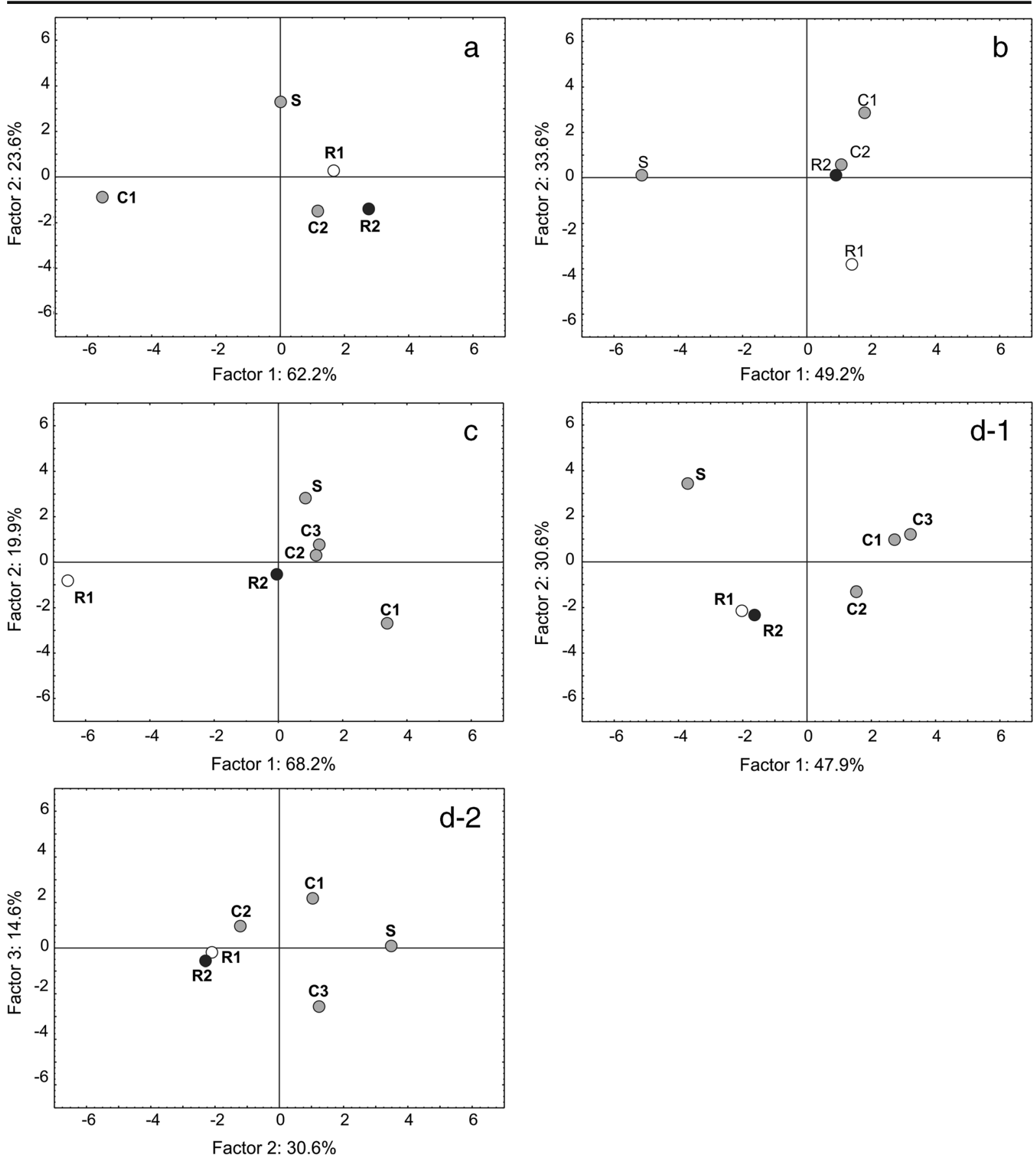

Fig. 8 Biplot of PCA scores performed on the environmental variables recorded under each hydrologic condition sampled: panel a high water (flooding); panel b mean flows; panel c low flows; and panels $\mathbf{d}$, very low flows in the tributaries, but with mean

flows in the Salado River (panel D-1, factors 1 and 2; panel D-2, factors 2 and 3 ). In the various panels, the different circles indicate the positions of the various sampling sites within the matrix

system, particularly to site $\mathrm{C} 2$, during mean flows and drought. The $\mathrm{Na}-\mathrm{Cl}-\mathrm{SO}_{4}$ water type along with the water's conductivity and hardness values all pointed to this relationship. In contrast, both river sampling sites

were closely related during the last survey, because of the extremely low discharge registered from the tributaries at that time. These differences in the multivariate findings suggest that the artificial canalizations modify 
Table 2 Correlations of factor variables in each hydrological survey: A, high water (flooding); B, mean flows; C, low flows (drought); D, very low flows (extreme drought) in the tributaries, with mean flows in the Salado-River

\begin{tabular}{|c|c|c|c|c|c|c|}
\hline \multicolumn{4}{|l|}{ A — high water (flooding) } & \multicolumn{3}{|l|}{$\mathrm{B}$-mean flows } \\
\hline Variables & Factor 1 & \multicolumn{2}{|l|}{ Factor 2} & Variables & Factor 1 & Factor 2 \\
\hline Conductivity & -0.98 & \multicolumn{2}{|l|}{-0.15} & $\mathrm{~N}-\mathrm{NH}_{4}^{+}$ & -0.99 & 0.03 \\
\hline Hardness & -0.99 & \multicolumn{2}{|l|}{-0.07} & TDP & -0.97 & -0.21 \\
\hline Turbidity & -0.96 & \multicolumn{2}{|l|}{-0.29} & DRP & -0.94 & -0.32 \\
\hline SS & -0.97 & \multicolumn{2}{|l|}{-0.24} & $\mathrm{TP}$ & -0.92 & -0.38 \\
\hline OM & -0.94 & \multicolumn{2}{|l|}{-0.31} & Flow velocity & 0.87 & 0.31 \\
\hline DO & 0.96 & \multicolumn{2}{|l|}{-0.17} & DO & -0.87 & -0.08 \\
\hline Secchi disk & 0.73 & \multicolumn{2}{|l|}{0.02} & $\mathrm{~N}+\mathrm{N}$ & -0.78 & -0.34 \\
\hline Dissolved polyphenols & -0.74 & \multicolumn{2}{|l|}{-0.35} & DOM & -0.73 & -0.29 \\
\hline Flow velocity & 0.40 & \multicolumn{2}{|l|}{-0.83} & Alkalinity & -0.1 & -0.94 \\
\hline Alkalinity & 0.57 & \multicolumn{2}{|l|}{0.81} & Turbidity & 0.49 & -0.86 \\
\hline $\mathrm{N}+\mathrm{N}$ & -0.81 & \multicolumn{2}{|l|}{0.56} & Conductivity & 0.39 & 0.84 \\
\hline DRP & 0.59 & \multicolumn{2}{|l|}{0.79} & $\mathrm{pH}$ & 0.57 & -0.81 \\
\hline TP & -0.84 & \multicolumn{2}{|l|}{0.38} & Secchi disk & -0.57 & 0.80 \\
\hline \multirow[t]{2}{*}{ TDP } & -0.85 & \multirow{2}{*}{\multicolumn{2}{|c|}{-0.11}} & $\mathrm{OM}$ & 0.65 & -0.73 \\
\hline & & & & SS & 0.65 & -0.73 \\
\hline \multicolumn{4}{|c|}{ D-very low flows (tributaries) and mean flows (river) } & \multicolumn{3}{|l|}{$\mathrm{C}$-low flows (drought) } \\
\hline Variables & Factor 1 & Factor 2 & Factor 3 & Variables & Factor 1 & Factor 2 \\
\hline DOM & -0.99 & 0.00 & 0.04 & Turbidity & -0.98 & -0.17 \\
\hline Flow velocity & -0.98 & 0.12 & -0.09 & $\mathrm{pH}$ & -0.98 & -0.14 \\
\hline DRP & -0.97 & 0.18 & -0.03 & TP & -0.98 & -0.11 \\
\hline Dissolved polyphenols & -0.94 & 0.06 & 0.24 & TDP & -0.97 & -0.08 \\
\hline TDP & -0.93 & 0.35 & 0.03 & DRP & -0.96 & -0.06 \\
\hline TP & -0.93 & 0.36 & 0.01 & Conductivity & 0.96 & -0.19 \\
\hline Secchi disk & 0.92 & 0.27 & -0.17 & DOM & -0.95 & -0.23 \\
\hline DO & -0.38 & -0.90 & -0.21 & Alkalinity & -0.94 & 0.28 \\
\hline SS & -0.48 & -0.86 & 0.11 & SS & -0.94 & -0.33 \\
\hline Hardness & -0.09 & -0.84 & 0.25 & $\mathrm{OM}$ & -0.93 & -0.36 \\
\hline $\mathrm{OM}$ & -0.57 & -0.80 & -0.03 & Secchi disk & 0.91 & -0.39 \\
\hline $\mathrm{pH}$ & 0.43 & -0.79 & -0.34 & Hardness & 0.89 & -0.32 \\
\hline Turbidity & -0.56 & -0.79 & -0.02 & Dissolved polyphenols & -0.70 & 0.57 \\
\hline $\mathrm{N}-\mathrm{NH}_{4}^{+}$ & -0.64 & 0.74 & 0.04 & DO & -0.33 & -0.88 \\
\hline Conductivity & 0.35 & -0.3 & 0.88 & $\mathrm{~N}-\mathrm{NH}_{4}{ }^{+}$ & 0.11 & 0.76 \\
\hline Alkalinity & 0.19 & -0.12 & 0.83 & $\mathrm{~N}+\mathrm{N}$ & -0.20 & 0.75 \\
\hline $\mathrm{N}+\mathrm{N}$ & -0.00 & -0.20 & -0.83 & & & \\
\hline
\end{tabular}

The italics indicates $>0.7$ positive or negative correlations

the chemical properties of the Salado-River downstream water, under certain specific hydrologic conditions, though not under others. The ionic composition of the water analyzed in this work are of notable relevance to future research, since the toxicity of salts and the relation between salinity and other chemical compounds is dependent on the water's ionic composition (CañedoArgüelles et al. 2013). Moreover, different water types have diverse effects on aquatic organisms when the latter are exposed to toxicants (e. g., pesticides, heavy metals; Buchwalter and Luoma, 2005; Zalizniak et al. 2009, Scheibener et al. 2016). 
Fig. 9 Cluster analysis (BrayCurtis similarity) of the total phytoplankton and zooplankton species composition at each sampling site during the surveys: high flows (hf), mean flows (mf), low flows (lf), very low flows (vlf) in the tributaries with mean flows $(\mathrm{mf} 2)$ in the river. The boldface denotes significant clades $(p<0.05)$

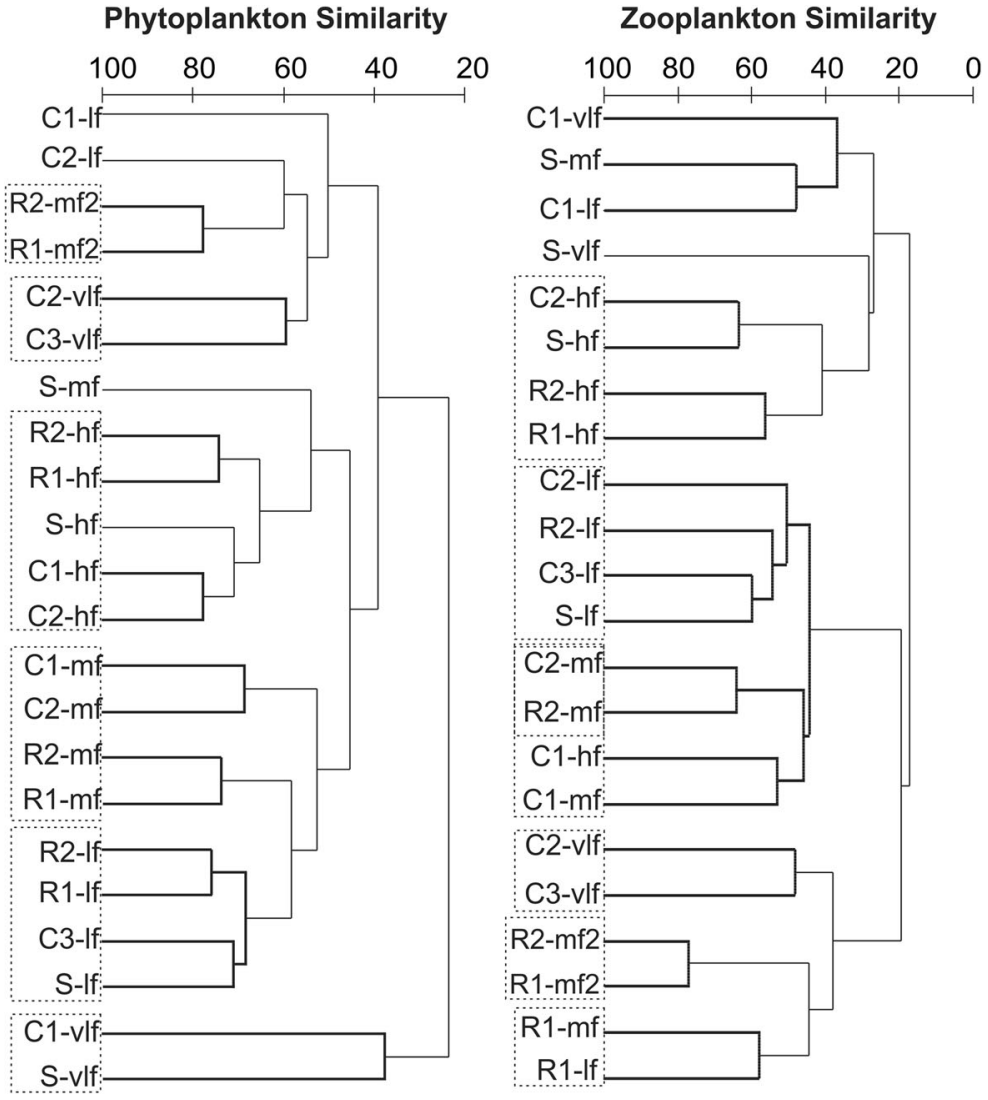

The DO was mostly related to the season and to the hydrologic regime. The low DO values observed in the high-water period could have resulted from oxygen depletion through allochthonous material oxidation. Turbidity, SS, OM, DOM, hardness, alkalinity, ion concentration, and chlorophyll- $a$ levels also registered their lowest values during flooding, owing to a dilution effect (Schagerl et al. 2009; Devercelli 2010).

The maximum values of SS and OM were observed during the mean-flow and low-water periods, probably because of a greater interaction with the riverbed (Gabellone et al. 2005; Picard and Lair 2005). In contradistinction, the dissolved-polyphenol concentrations were higher during the flooding, but exhibited the lowest values during the extreme drought, in accordance with previous studies (Neschuk 2001).

The nutrient concentrations displayed a local distribution pattern, particularly in the tributaries, reaching the highest values at site $\mathrm{S}$ in the Saladillo Stream. According to the PCA results, the latter sampling site was positively associated with higher values of $\mathrm{N}-\mathrm{NH}_{4}{ }^{+}$, $\mathrm{N}+\mathrm{N}$, DRP, TP, and TDP, and negatively correlated with the DOs under all hydrologic conditions. The TP values observed at this site in particular were within the range established for a septic effluent (Withers and Jarvie 2008). This finding could well be related to the sewage emissions from the city of Bragado, registered in the stream's headwaters. Unprocessed wastewater discharges generate first hypoxia, then anoxia; and in so doing elevate the ammonium concentrations (Meybeck 2003). Likewise, $\mathrm{N}-\mathrm{NH}_{4}{ }^{+}$peaks had been associated with sewage discharges in the Thames River (Jarvie et al. 2002); and similar elevations were observed for TP, DRP, and TDP concentrations in other UK rivers (Neal et al. 2010). In addition, previous studies in other streams of the Salado-River basin have recorded high TP values and eutrophic water in relation to point sources of pollution and sewage discharge (Feijoó and Lombardo 2007). In spite of the high nutrient concentrations registered especially at the stream site (S) in the present work, no similar increase was observed at the river's downstream site (R2); rather, the opposite pattern was obtained. This discrepancy could be related to the upstream discharge of the canal at $\mathrm{C} 3$, which water contained very 
low levels of TP and TN, thus diluting out the river's nutrient load. The influence of tributaries in nutrient dilution had also previously been reported in the basin (Neschuk 2001).

In view of the TP values registered, the Salado River is classified as eutrophic (Dodds et al. 1998; Gabellone et al. 2013a). Despite the volcanic P-rich-loess deposition occurring during the Quaternary Period that is a geologic condition peculiar to the pampas plain, current phosphorus loadings there are mostly related to agricultural activities and wastewater discharges, especially in the Salado-River upper basin (Neschuk 2001). Increases in nutrient concentrations coinciding with the presence of human populations have been regularly observed in other rivers of the region (José de Paggi and Devercelli 2011) as well as worldwide (Weilhoefer et al. 2008; Kröger et al. 2013).

In the Salado River, the TP and DRP concentrations were associated with the hydrologic regime, with minimum values occurring during flooding through dilution and maximum levels in times of low flows. Forms of particulate $\mathrm{P}$ predominated during low flows and drought; but dissolved species were present during flooding, as had been observed previously in the Danube River (Schagerl et al. 2009) and in UK rivers (Neal et al. 2010). Conversely, in the Rhine River the forms of dissolved $\mathrm{P}$ had been found to remain at low concentrations throughout the year (de Ruyter van Steveninck et al. 1992). In accordance with previous studies on the Salado, the TP and PP concentrations became quite elevated during low flows and also coincided with spring tillage activities (Neschuk 2001; Gabellone et al. 2013a).

$\mathrm{P}$ compounds have been recognized as accumulating in fluvial systems, particularly during the springsummer low flows, thus increasing the risk of eutrophication (Kronvang et al. 2007; Jarvie et al. 2008; Withers and Jarvie 2008). In addition, the dissolved inorganic-N fraction consisted predominantly in $\mathrm{N}-\mathrm{NO}_{3}{ }^{-}$, whereas $\mathrm{N}-\mathrm{NH}_{4}{ }^{+}$and $\mathrm{N}-\mathrm{NO}_{2}{ }^{-}$were present at much lower levels, as had been registered in other lowland rivers (Descy and Gosselain, 1994). The TN concentrations recorded by us in the Salado River were higher than those observed in the Po River (Rossetti et al. 2009) and in rivers in the USA as well (Koch et al. 2004).

The availability of $\mathrm{P}$ is also linked to sorption on and into the clay particles $(<2 \mu \mathrm{m})$ that are regularly present in river sediments and suspended solids (House and Denison 1998; Garnier et al. 2005). The significant regression coefficients between TP, PP, and SS found in this survey could be attributable to those sorptions and also to agricultural runoff (Bechmann et al. 2005).

The presence of $\mathrm{N}_{-} \mathrm{NO}_{3}{ }^{-}$and DRP in the surface water of arable lands is likewise closely related to agricultural practices (Jarvie et al. 2002). According to Woltemade (2000), cropland runoff substantially degrades water quality. Nonpoint sources of pollution, such as agriculture, can magnify local problems of eutrophication in the pampas region (Vilches et al. 2011). Accordingly, Mugni (2008) had determined that fertilizers increased DRP concentrations in pampean streams via surface runoff during heavy rainfalls.

In the drainage canals, the DRP concentrations declined as the water level and the current velocity dropped. This relationship can be explained by biologic consumption since these canals drain various wetlands and saline shallow lakes within the study area, which environments are widely known to be nutrient sinks (Hein et al. 1999, 2005; Reddy et al. 1999). The retention capacity of these lentic environments is based on their characteristic reduction in flow velocity and the consequent generation of longer water-residence times, which kinetics enables an increase in nutrient uptake and the deposition of particulate material (Jarvie et al. 2008).

The N:P ratios observed were similar to those previously cited for the Salado-River middle basin (Moscuzza et al. 2007). All of those values were lower than the Redfield ratio and also less than those cited for North-American and New-Zealand streams (Dodds et al. 2002). For their part, Neal et al. (2006) considered that $100 \mu \mathrm{g} \mathrm{P}-\mathrm{PO}_{4} \mathrm{~L}^{-1}$ overcame nutritional limitations on algal concentrations, which values were substantially exceeded in the present findings. P limitations, however, are usual in the Thames (Jarvie et al. 2002) and in the Mississippi (Turner et al. 2003) rivers; though, nevertheless, a strong nitrogen imbalance has been documented in certain other rivers in the USA (Hunt et al. 2005).

Chlorophyll- $a$ values and the plankton biomass exhibited a seasonal pattern with marked shifts as a function of temperature and the hydrologic regime, which parameters regularly act as key controlling influences in temperate rivers (Lair 2006; Neal et al. 2006; Schagerl et al. 2009). Thus, the chlorophyll- $a$ levels and the phytoplankton and zooplankton biomasses dropped to minimum values during the autumn flooding - probably owing to the shortened photoperiods during the season, to low temperatures, and to the dilution effected by the inundation (Neschuk 2001; Garnier et al. 2005). An inverse relationship between plankton development 
and water discharge is a common feature in other lowland rivers of the region (de Cabo et al. 2003; Devercelli 2010) as well as worldwide (de Ruyter van Steveninck et al. 1992; Thorp et al. 1994; Basu and Pick 1996). As a whole, river flow, floodings, and hydrological connectivity act as drivers of the biota's structural and functional properties, thus maintaining its dynamic (Kobayashi et al. 2015).

Recent studies in stream mesocosms (CañedoArgüelles et al. 2014) indicated that salt pulses reduced chlorophyll- $a$ levels and other functional descriptors of the benthic community. In contrast, chlorophyll- $a$ concentrations became increased in treatments where salt concentrations diminished the density of the algal predators, so as to trigger cascade effects (Cañedo-Argüelles et al. 2016b). In addition, Pilkaitytë et al. (2004), in mesocosm experiments, found that the phytoplankton biomass of brackish-water systems, measured as chlorophyll- $a$ levels, was affected by elevations in salinity. Whether or not the phytoplankton of the study area responds to chronic or pulsed salt disturbances remains unexplored along with the consequences of such perturbations on the plankton community, especially at the river's site (R2) downstream from the canal system's discharge at sites $\mathrm{S}$ and $\mathrm{C} 3$.

The highest values of phytoplankton and zooplankton richness were recorded during the high-water period, probably resulting from the hydrological connectivity between the river and its floodplain (Reynolds and Descy 1996; Izaguirre et al. 2001; Wahl et al. 2008; Devercelli 2010). Site C2 registered the highest values of cumulative species richness for the phytoplankton and zooplankton that were observed throughout the four hydrologic conditions. That site's particular geomorphological feature - that is, being a canal that links the wetland between the Municipal and Bragado shallow lakes - most likely encourages the formation and maintenance of a highly rich plankton community. Accordingly, wetlands have been recognized as heterogeneous environments capable of harboring diverse communities; moreover, lake effluents are well known to contribute lentic and sporadic species to the river downstream (Rojas Molina and José de Paggi 2008). Consequently, at the river's downstream site (R2), an elevation in the total phytoplankton and zooplankton species richness was observed, particularly in the high-water period. Furthermore, the lentic environments connected with the river-such as the wetlands and shallow lakes present in the study area - have been recognized as acting as sources of plankton inocula that ultimately reach the river's main course (Neal et al. 2006; Wahl et al. 2008; Claps et al. 2009).

In the work reported here, the total phytoplankton and zooplankton species richness found was higher than those previously mentioned for the Salado-River basin (Neschuk 2001; Claps et al. 2009). This difference could be related to the inclusion of the watercourses with different geomorphological features (i. e., the drainage canals to the stream and river) under the same contrasting hydrologic conditions (i. e., flooding, mean flows, drought). In this context, in floodplain rivers floodings and droughts are considered as disturbance pulses that provide of spatiotemporal heterogeneity and a diversity of habitats for community assembly (Junk et al. 1989). The remarkable species richness registered in this investigation - 604 taxa in all-would testify to the resilient character of the plankton community, and also its redundancy, within the study area. The latter feature may simply act as a natural insurance against species loss (Walker 1992), such as in the example of species replacement after a disturbance. In this way, Gabellone et al. (2013b) mentioned that the plankton community of the Salado River is resilient since that biota is well adapted to the river's hydrological regime and to the concomitant changes in water conductivity.

The plankton was characterized by chlorococcal cholorophytes and rotifers, groups that frequently prevail in fluvial ecosystems because of their tolerance to lotic conditions and disturbance (Rossetti et al. 2009). The rotifers were a quite diverse group, particularly at the C2 sampling site (66 cumulative taxa), with this richness value being comparable to those found in billabongs of Australian rivers (Shiel \& Koste, 1983). Of the phytoplankton, the diatoms were well represented among the sampling sites, especially at Site $S$ in the Saladillo Stream because of the stream's shallow course and nutrient-enriched waters that would have served to improve the development of the benthos community. In addition, at that site many euglenoids and ciliate species were also registered, most of which are normally associated with water polluted with organic matter and nutrients (Bazzuri et al. 2010). The $\mathrm{S}$ site, however, registered the minimum values of total zooplankton richness within the surveys, probably owing to the high levels of ammonia, which cation is deleterious to zooplanktonic organisms producing serious toxic effects (José de Paggi and Paggi 1998). The presence of elevated values of rotifer and ciliate species richness registered at the 
drainage system was closely related to the trophic status of that water (José de Paggi and Paggi 1998). As a consequence of the discharge from the tributary canals, many rotifer and ciliate species were added to the river's water, in detriment to the rhizopod, cladoceran, and copepod species richness recorded at site R2, with the former two being taxa that had the highest cumulative richness upstream at site R1.

The diverse sampling sites studied (i. e., in the canals, the Stream, and the Salado River) differed among the hydromorphologic features that are recognized as relevant conditions for nutrient retention and acceptable water quality, on the basis of the implied waterresidence times (Reddy et al. 1999). In particular, the canals passing through $\mathrm{C} 1$ and $\mathrm{C} 3$ are trapezoidal in cross-section, which construction increases water discharges and flow velocities, thus facilitating downstream transport. According to the telescoping ecosystem model (Fisher et al. 1998), the degree of meandrous sinuosity exhibited by a stream increases its nutrient retention and reduces its processing length because of a more prolonged lateral connectivity. Moreover, this model considers that a watercourse's configuration reduces the response to disturbance since the resilience of the system depends on its interactions with the subsystems and on the latters' sensitivity to sudden change. From this standpoint, an opposite situation was registered for the drainage canals studied here; which watercourses run in a straight line, have steep banks, and contain scanty parafluvial vegetation, thus producing a lower degree of lateral interaction among the subsystems. In addition, the lower development of macrophytes and their associated communities has reduced the moderation of the terrestrial runoff that would otherwise occur. These geomorphologic characteristics have limited the canals' resilience, as would have been expressed by wider values in the physicochemical variables and in the phytoplankton and zooplankton species richness throughout the four surveys - in comparison, for example, to those same parameters observed at the river's upstream site (R1).

The wetlands and shallow lakes present within the study area have acted as service ecosystems by reducing salt concentration, suspended solids, organic matter, and nutrient levels in the effluent water of the canals. Those water bodies furthermore facilitated the increase in the total phytoplankton and zooplankton biomasses along with the higher species richness at the river's downstream site R2. These benefits were clearly seen during flooding; where conductivity, ion concentrations, turbidity, suspended solids, organic matter, TP, dissolved polyphenols, chlorophyll $a$, and total plankton biomasses were present in a gradient along the canalizations. This system of interconnected canals and lentic environments is of critical value to the Salado-River upper basin, since that network of canals reduces the impact of the saline canalizations on the river's downstream site. Indeed, floodplains and wetlands are widely regarded as sinks for nutrients and pollutants that would otherwise reach the river system via wastewaters, tributary discharge, and agricultural runoff (Zalewski 2007; Reddy and De Laune 2008; Lair et al. 2009). In fluvial environments, hydrology is considered to be the essential determinant of an associated wetland's structure and functional properties, as such controlling the biogeochemical cycling therein (Wolf et al. 2013).

More efficient fertilization strategies are required in order to reduce nutrient loads and to avoid groundwater pollution within the environs of the Salado River. The land-use practices along with biogeochemical processes occurring in the wetlands and streams of the basin would then reduce the input of $\mathrm{P}$, as has been observed in other lotic systems of the pampas region (Mugni 2008) as well as worldwide (Reddy et al. 1999; Honti et al. 2010).

\section{Conclusions}

The sandy-pampa canalizations constitute a complex hydrologic system characterized by particular geomorphologic features and a strong influence of saline groundwater. These canalizations facilitate the incorporation of salt-laden water into the Salado-River basin under all conditions. This network, however, also extracts the quality freshwater arising from the underlying aquifers during flooding. As Cañedo-Argüelles et al. (2013) pointed out, the management of secondary salinization should be directed towards comprehensive catchment strategies. Within this context, in view of the extensive and relentless salinization that invariably irreversibly damages the soil's structure and restricts the use of the water, a careful management of the canals' environment would be required that limited agriculture and other economic activities in the region.

The influence of the drainage-channel discharges into the Salado River was clearly observed in the water's chemical characteristics and in the total phytoplankton and zooplankton biomasses, species richness, and 
plankton compositions. Consequently, the characteristics of the river's downstream site (R2) was closely related to those of $\mathrm{C} 2$ in the mean-flow and low-water surveys. In contrast, the upstream site (R1) remained significantly related to itself under the first three hydrologic conditions - i. e., high water, mean flows, and low flows - and became comparable to R2 in only the last survey - at a time of extreme drought with minimal inflows from the tributaries along with mean flows prevailing in the river.

The information garnered by this research is of relevance to the well-being of the Salado-River watershed, since additional hydraulic constructions have been planned for the study area- the most notable of those involving a direct discharge of $\mathrm{C} 1$ into the Salado River, without passing through the wetlands and shallow lakes of the study area. In such a circumstance, a greater impact on the river's downstream site (R2) would be expected through the avoidance of those lentic environments, where the saline and allochthonous conditions of the input water into the canals is otherwise reduced.

Acknowledgements This research was supported by the Agencia Nacional de Promoción Científica y Tecnológica (ANPCyT, Argentina), and the paper constitutes Scientific Contribution $\mathrm{N}^{\circ} 1,000$ of the Institute of Limnology Dr. Raúl A. Ringuelet (ILPLA, CCT La Plata CONICET, UNLP). We are most grateful to Dr. Hernán Benítez for his help in the laboratory procedures, and we would like to thank the anonymous reviewers for their useful comments on the manuscript. María Elisa Bazzuri holds a fellowship from Comisión Nacional de Investigaciones Científicas y Técnicas CONICET (Argentina). Dr. Donald F. Haggerty, a retired academic career investigator and native English speaker, edited the final version of the manuscript.

Compliance with ethical standards The authors declare that they have no conflict of interest. This article does not contain any studies with human participants or animals performed by any of the authors.

\section{References}

American Public Health Association (1995). Standard Methods for the Examination of Water and Wastewater. 19th Ed. Washington, D.C: APHA.

Amoros, C., \& Bornette, G. (2002). Connectivity and biocomplexity in waterbodies of riverine floodplains. Freshwater Biology, 47(4), 761-776. https://doi. org/10.1046/j.1365-2427.2002.00905.x.

Andersen, T., \& Hessen, D. O. (1991). Carbon, nitrogen, and phosphorus content of freshwater zooplankton. Limnology \& Oceanography, 36(4), 807-814. https://doi.org/10.4319 /o.1991.36.4.0807.

Aradas, R. D., Lloyd, J., Wicks, J., Palmer, J. (2002). Groundwater problems in low elevations regional plains: the Buenos Aires province example. In: E. Bocanegra, D. Martínez, \& H. Massone (Eds), Groundwater and Human Development (pp 613-623). Proceedings XXXII IAH and VI AHL SUD Congress, Mar del Plata, Argentina.

Badano, N. D. (2010). Modelación integrada de grandes cuencas de llanura con énfasis en la evaluación de inundaciones. Graduate Tesis: FIUBA, Universidad Nacional de Buenos Aires.

Basú, B. K., \& Pick, F. R. (1996). Factors regulating phytoplankton and zooplankton biomass in temperate rivers. Limnology \& Oceanography, 41, 1572-1577.

Bazzuri, M. E., Gabellone, N. A., \& Solari, L. C. (2008). Variación estacional de fitoplancton en la cuenca inferior del Río Salado (Prov. Buenos Aires). Biología Acuática, 24, 137-148.

Bazzuri, M. E., Gabellone, N. A., \& Solari, L. C. (2010). Seasonal variation in the phytoplankton during an intensive sampling period in a saline lowland river (Buenos Aires, Argentina). River Research \& Applications, 26, 766-778.

Bechmann, M. E., Berge, D., Eggestad, H. O., \& Vandsemb, S. M. (2005). Phosphorus transfer from agricultural areas and its impact on the eutrophication of lakes - two long-term integrated studies from Norway. Journal of Hydrology, 304(1-4), 238-250. https://doi.org/10.1016/j.jhydrol.2004.07.032.

Bottrell, H. H., Duncan, A., Gliwicz, Z. M., Grygierek, E., Herzig, A., Hillbricht-Ilkowska, A., Kurasawa, H., Larsson, P., \& Weglenska, T. (1976). A review of some problems in zooplankton production studies. Norwegian Journal of Zoology, 24, 419-456.

Buchwalter, D. B., \& Luoma, S. N. (2005). Differences in dissolved cadmium and zinc uptake among stream insects: mechanistic explanations. Environmental Science \& Technology, 39(2), 498-504. https://doi.org/10.1021 les0404421.

Cañedo-Argüelles, M., Bundschuh, M., Gutiérrez-Cánovas, C., Kefford, B. J., Prat, N., Trobajo, R., \& Schäfer, R. B. (2014). Effects of repeated salt pulses on ecosystem structure and functions in a stream mesocosm. Science of the Total Environment, 476, 634-642.

Cañedo-Argüelles, M., Hawkins, C. P., Kefford, B. J., Schäfer, R. B., Dyack, B. J., Brucet, S., Buchwalter, D., Dunlop, J., Frör, O., Lazorchak, J., Coring, E., Fernandez, H. R., Goodfellow, W., González Achem, A. L., Hatfield-Dodds, S., Karimov, B. K., Mensah, P., Olson, J. R., Piscart, C., Prat, N., Ponsá, S., Schulz, C.-J., \& Timpano, A. J. (2016a). Saving freshwaters from salts. Science, 351(6276), 914-916. https://doi. org/10.1126/science.aad3488.

Cañedo-Argüelles, M., Kefford, B. J., Piscart, C., Prat, N., Schäfer, R. B., \& Schulz, C. J. (2013). Salinisation of rivers: an urgent ecological issue. Environmental Pollution, 173, 157-167. https://doi.org/10.1016/j.envpol.2012.10.011.

Cañedo-Argüelles, M., Sala, M., Peixoto, G., Prat, N., Faria, M., Soares, A. M. V. M., Barata, C., \& Kefford, B. (2016b). Can salinity trigger cascade effects on streams? A mesocosm approach. Science of the Total Environment, 540, 3-10. https://doi.org/10.1016/j.scitotenv.2015.03.039.

Carol, E. S., Kruse, E., \& Pousa, J. L. (2010). Eco-hydrological role of deep aquifers in the Salado sedimentary basin in the Province of Buenos Aires, Argentina. Environmental Earth Sciences, 60(4), 749-756. https://doi.org/10.1007/s12665009-0212-4. 
Carpenter, S. R. (2008). Phosphorus control is critical to mitigating eutrophication. Proceedings of the National Academy of Sciences, 105, 11039-11040.

Carpenter, S. R., Caraco, N. F., Correll, D. L., Howarth, R. W., Sharpley, A. N., \& Smith, V. H. (1998). Nonpoint pollution of surface waters with phosphorus and nitrogen. Ecological Applications, 8(3), 559-568.

Claps, M. C., Gabellone, N. A., \& Neschuk, N. C. (2009). Influence of regional factors on zooplankton structure in a saline lowland river: the Salado River (Buenos Aires Province, Argentina). River Research \& Applications, 25(4), 453-471. https://doi.org/10.1002/rra.1182.

Cesanelli, A., \& Guarracino, L. (2011). Estimation of regional evapotranspiration in the extended Salado Basin (Argentina) from satellite gravity measurements. Hydrogeology Journal, 19(3), 629-639. https://doi. org/10.1007/s10040-011-0708-3.

De Cabo, L., Puig, A., Arreghini, S., Olguín, H. F., Seoane, R., \& Obertello, I. (2003). Physicochemical variables and plankton from the Lower Delta of the Paraná River (Argentina) in relation to flow. Hydrological Processes, 17(7), 1279-1290. https://doi.org/10.1002/hyp.1284.

De Ruyter Van Steveninck, E. D., Admiraal, W., Brebaart, L., Tubbing, G. M. J., \& Van Zanten, B. (1992). Plankton in the River Rhine: structural and functional changes observed during downstream transport. Journal of Plankton Research, 14(10), 1351-1368. https://doi.org/10.1093/plankt/14.10.1351.

Descy, J.-P., \& Gosselain, V. (1994). Development and ecological importance of phytoplankton in a large lowland river (River Meuse, Belgium). Hydrobiologia, 289(1-3), 139-155. https://doi.org/10.1007/BF00007415.

Devercelli, M. (2010). Changes in phytoplankton morphofunctional groups induced by extreme hydroclimatic events in the Middle Paraná River. Hydrobiologia, 639(1), 5-19. https://doi.org/10.1007/s10750-009-0020-6.

Dodds, W. K., Jones, J. R., \& Welch, E. B. (1998). Suggested classification of stream trophic state: distributions of temperate stream types by chlorophyll, total nitrogen, and phosphorus. Water Research, 32(5), 1455-1462. https://doi. org/10.1016/S0043-1354(97)00370-9.

Dodds, W. K., Smith, V. H., \& Lohman, K. (2002). Nitrogen and phosphorus relationships to benthic algal biomass in temperate streams. Canadian Journal of Fisheries \& Aquatic Sciences, 59(5), 865-874. https://doi.org/10.1139/f02-063.

Dumont, H. J., Van de Velde, I., \& Dumont, S. (1975). The dry weight estimate of biomass in a selection of Cladócera, Copépoda and Rotífera from the plankton, periphyton and bentos of continental waters. Oecologia, 19(1), 75-97. https://doi.org/10.1007/BF00377592.

Ensign, S. H., \& Doyle, M. W. (2006). Nutrient spiraling in streams and river networks. Journal of Geophysical Research: Biogeosciences, 111(G4). https://doi.org/10.1029 /2005JG000114.

Feijoó, C. S., \& Lombardo, R. J. (2007). Baseline water quality and macrophyte assemblages in Pampean streams: a regional approach. Water Research, 41(7), 1399-1410. https://doi. org/10.1016/j.watres.2006.08.026.

Fisher, S. G., Grimm, N. B., Martí, E., Holmes, R. M., \& Jones Jr., J. B. (1998). Material spiraling in stream corridors: a telescoping ecosystem model. Ecosystems, 1(1), 19-34. https://doi.org/10.1007/s100219900003.
Forte Lay, J. A., Kruse, E., \& Aiello, J. L. (2007). Hydrologic scenarios applied to the agricultural management of the northwest of the Buenos Aires Province, Argentina. GeoJournal, 70(4), 263-271. https://doi.org/10.1007 /s10708-008-9140-1.

Gabellone, N. A., Claps, M. C., Solari, L. C., \& Neschuk, N. C. (2005). Nutrients, conductivity and plankton in a landscape approach to a Pampean saline lowland river (Salado River, Argentina). Biogeochemistry, 75(3), 455-477. https://doi. org/10.1007/s10533-005-3273-9.

Gabellone, N. A., Claps, M. C., Solari, L. C., Neschuk, N. C., \& Ardohain, D. M. (2013a). Spatial and temporal distribution pattern of phosphorus fractions in a saline lowland river with agricultural land use (Salado River, Buenos Aires, Argentina). Fundamental \& Applied Limnology, 183, 271286.

Gabellone, N. A., Solari, L. C., Claps, M. C., \& Neschuk, N. C. (2008). Chemical classification of the water in a lowland river basin (Salado River, Buenos Aires, Argentina) affected by hydraulic modifications. Environmental Geology, 53(6), 1353-1363. https://doi.org/10.1007/s00254-007-0745-3.

Gabellone, N. A., Solari, L. C., Casco, M. A., \& Claps, M. C. (2013b). Conservación del plancton y protección de las cuencas hídricas. AUGMDOMUS, 5, 100-119.

Garnier, J., Némery, J., Billen, G., \& Théry, S. (2005). Nutrient dynamics and control of eutrophication in the Marne River system: modeling the role of exchangeable phosphorus. Journal of Hydrology, 304(1-4), 397-412. https://doi. org/10.1016/j.jhydrol.2004.07.040.

Ghersa, C. M., De La Fuente, E., Suarez, S., \& Leon, R. J. C. (2002). Woody species invasion in the Rolling Pampa grasslands, Argentina. Agriculture, Ecosystems \& Environments, 88(3), 271-278. https://doi.org/10.1016/S0167-8809(01 00209-2.

González, M. H., \& Fernández, A. E. (2007). Floods increasing in Buenos Aires Salado River basin, Argentina. In O. Scarpati \& A. Jones (Eds.), Environmental change and rational water use (pp. 96-113). Orientación Gráfica Editora: Buenos Aires.

Hart, B. T., Lake, P. S., Webb, J. A., \& Grace, M. R. (2003). Ecological risk to aquatic systems from salinity increases. Australian Journal of Botany, 51(6), 689-702. https://doi. org/10.1071/BT02111.

Hein, T., Heiler, G., Pennetzdorfer, D., Riedler, P., Schagerl, M., \& Schiemer, F. (1999). The Danube restoration project: functional aspects and planktonic productivity in the floodplain system. Regulated Rivers: Research \& Management, 15(13), 259-270. https://doi.org/10.1002/(SICI)1099-1646 (199901/06)15:1/3<259::AID-RRR539>3.0.CO;2-E.

Hein, T., Reckendorfer, W., Thorp, J. H., \& Schiemer, F. (2005). The role of slackwater areas for biogeochemical processes in rehabilitated river corridors: examples from the Danube. Archiv fur Hydrobiologie Supplement, 155, 425-442.

Herczeg, A. L., Dogramaci, S., \& Leaney, F. (2001). Origin of dissolved salt in a large, semi-arid groundwater system: Murray basin, Australia. Marine \& Freshwater Research, 52(1), 41-53. https://doi.org/10.1071/MF00040.

Hillebrand, H., Dürselen, C.-D., Kirschtel, D., Pollingher, U., \& Zohary, T. (1999). Biovolume calculation for pelagic and benthic microalgae. Journal of Phycology, 35(2), 403-424. https://doi.org/10.1046/j.1529-8817.1999.3520403.x. 
Honti, M., Istvánovics, V., \& Kovács, Á. S. (2010). Balancing between retention and flushing in river networks - optimizing nutrient management to improve trophic state. Science of the Total Environment, 408(20), 4712-4721. https://doi. org/10.1016/j.scitotenv.2010.06.054.

House, W. A., \& Denison, F. H. (1998). Phosphorus dynamics in a lowland river. Water Research, 32(6), 1819-1830. https://doi. org/10.1016/S0043-1354(97)00407-7.

Hunt, C. W., Loder Iii, T., \& Vörösmarty, C. (2005). Spatial and temporal patterns of inorganic nutrient concentrations in the Androscoggin and Kennebec Rivers, Maine. Water, Air, \& Soil Pollution, 163(1-4), 303-323. https://doi.org/10.1007 /s11270-005-0880-y.

Imbellone, P. A., \& Giménez, J. E. (1998). Parent materials, buried soils and fragipans in northwestern Buenos Aires province, Argentina. Quaternary Interntional, 51, 115-126.

Iriondo, M., \& Kröhling, D. (2007). Geomorfología y sedimentología de la cuenca superior del río Salado (Sur de Santa Fe y NO de Buenos Aires, Argentina). Latin American Journal of Sedimentology and Basin Analysis, 14, 1-23.

Izaguirre, I., O'Farrell, I., \& Tell, G. (2001). Variation in phytoplankton composition and limnological features in a waterwater ecotone of Lower Paraná Basin (Argentina). Freshwater Biology, 46, 63-74.

Jarvie, H. P., Lycett, E., Neal, C., \& Love, A. (2002). Patterns in nutrient concentrations and biological quality indices across the upper Thames river basin, UK. Science of the Total Environment, 282, 263-294.

Jarvie, H. P., Withers, P. J., Hodgkinson, R., Bates, A., Neal, M., Wickham, H. D., Arman, S. A., \& Armstrong, L. (2008). Influence of rural land use on stream water nutrients and their ecological significance. Journal of Hydrology, 350(3-4), 166-186. https://doi.org/10.1016/j.jhydrol.2007.10.042.

José de Paggi, S. B. J., \& Devercelli, M. (2011). Land use and basin characteristics determine the composition and abundance of the microzooplankton. Water, Air, \& Soil Pollution, 218(1-4), 93-108. https://doi.org/10.1007 /s11270-010-0626-3.

José de Paggi, S. J., \& Paggi, J. C. (1998). Zooplancton de ambientes acuáticos con diferente estado trófico y salinidad. Neotropica, 44, 95-106.

Junk, W. J., Bayley, P. B., \& Sparks, R. E. (1989). The flood pulse concept in river-floodplain systems. In: D. P. Dodge (Ed), Proceedings of the International Large River Symposium. Canadian Special Publication of Fisheries \& Aquatic Sciences, 106, 110-117.

Karayanni, H., Christaki, U., Van Wambeke, F., \& Dalby, A. P. (2004). Evaluations of double formalin-Lugol's fixation in assessing number and biomass of ciliates: an example of estimation at mesoscale in NE Atlantic. Journal of Microbiological Methods, 56(3), 349-358. https://doi. org/10.1016/j.mimet.2003.11.002.

Kefford, B. J., Papas, P. J., Crowther, D., \& Nugegoda, D. (2002). Are salts toxicants? Australasian Journal of Ecotoxicology, $8,63-68$.

Kefford, B. J., Buchwalter, D., Cañedo-Argüelles, M., Davis, J., Duncan, R. P., Hoffmann, A., \& Thompson, R. (2016). Salinized rivers: degraded systems or new habitats for salttolerant faunas? Biology Letters, 12(3), 20151072. https://doi.org/10.1098/rsbl.2015.1072.
Kiedrzyńska, E., \& Zalewski, M. (2012). Water quality improvement through an integrated approach to point and non-point sources pollution and management of river floodplain wetlands. Ecological Water Quality-Water Treatment and Reuse, 325-342.

Kirk, J. T. O. (1983). Light and photosynthesis in aquatic ecosystems. Cambridge: Cambridge University Press.

Kobayashi, T., Ralph, T. J., Ryder, D. S., Hunter, S. J., Shiel, R. J., \& Segers, H. (2015). Spatial dissimilarities in plankton structure and function during flood pulses in a semi-arid floodplain wetland system. Hydrobiologia, 747(1), 19-31. https://doi.org/10.1007/s10750-014-2119-7.

Koch, R. W., Guelda, D. L., \& Bukaveckas, P. A. (2004). Phytoplankton growth in the Ohio, Cumberland and Tennessee Rivers, USA: inter-site differences in light and nutrient limitation. Aquatic Ecology, 38(1), 17-26. https://doi.org/10.1023/B:AECO.0000021082.42784.03.

Kröger, R., Dunne, E. J., Novak, J., King, K. W., Mclellan, E., Smith, D. R., Strock, J., Boomer, K., Tomer, M., \& Noe, G. B. (2013). Downstream approaches to phosphorus management in agricultural landscapes: regional applicability and use. Science of the Total Environment, 442, 263-274. https://doi.org/10.1016/j.scitotenv.2012.10.038.

Kronvang, B., Hoffmann, C. C., Svendsen, L. M., Windolf, J., Jensen, J. P., \& Dørge, J. (1999). Retention of nutrients in river basins. Aquatic Ecology, 33(1), 29-40. https://doi. org/10.1023/A:1009947907811.

Kronvang, B., Vagstad, N., Behrendt, H., Bøgestrand, J., \& Larsen, S. E. (2007). Phosphorus losses at the catchment scale within Europe: an overview. Soil Use \& Management, 23(s1), 104-116. https://doi.org/10.1111/j.14752743.2007.00113.x.

Kruse, E., Carol, E., Deluchi, M., Laurencena, P., \& Rojo, A. (2010). Hidroquímica subterránea en un sector de la zona deprimida del Salado. Azul: Provincia de Buenos Aires. Dissertation I Congreso Internacional de Hidrología de Llanuras.

Kruse, E., \& Laurencena, P. (2005). Aguas superficiales. Relación con el régimen subterráneo y fenómenos de anegamiento. In R. E. De Barrio, R. O. Etcheverry, M. F. Caballé, \& E. Llambías (Eds), Geología y recursos naturales de la Provincia de Buenos Aires (pp. 313-326). $16^{\circ}$ Congreso Geológico Argentino.

Kruse, E., \& Zimmermann, E. D. (2002). Hidrogeología de grandes llanuras, particularidades en la llanura pampeana (Argentina). In: E. Bocanegra, D. Martínez, \& H. Massone (Eds), Groundwater and Human Development (pp 20252038). Proceedings XXXII IAH and VI AHL SUD Congress, Mar del Plata, Argentina.

Lair, G. J., Zehetner, F., Fiebig, M., Gerzabek, M. H., Van Gestel, C. A. M., Hein, T., Hohensinner, S., Hsuf, P., Jones, K. C., Jordan, G., Koelmans, A. A., Poot, A., Slijkerman, D. M. E., Totsche, K. U., Bondar-Kunze, E., \& Barth, J. A. C. (2009). How do long-term development and periodical changes of river-floodplain systems affect the fate of contaminants? Results from European rivers. Environmental Pollution, 157(12), 33363346. https://doi.org/10.1016/j.envpol.2009.06.004.

Lair, N. (2006). A review of regulation mechanisms of metazoan plankton in riverine ecosystems: aquatic habitat versus biota. River Research \& Applications, 22(5), 567-593. https://doi. org/10.1002/rra.923. 
Lawrence, S. G., Malley, D. F., Findlay, W. J., Maclver, M. A., \& Delbaere, I. L. (1987). Method for estimating dry weight of freshwater planktonic crustaceans from measures of length and shape. Canadian Journal of Fisheries \& Aquatic Sciences, 44, 264-274.

Ludueña, S. G. (2006). Farm-scale pounding susceptibility for potential land reclamation assessment in large flatlands, $A$ case study in the Salado River Basin, Bs. As., Argentina. The Netherlands: Magister Tesis in Science in Geoinformation Science and Earth Observation. ITC.

Margalef, R. (1983). Limnología. Barcelona: Ediciones Omega.

Mc-Cauley, E. (1984). The estimation of the abundance and biomass of zooplankton in samples. In J. Downing \& F. Rigler (Eds.), A manual on methods for the assessment of secondary productivity in fresh waters (pp. 228-265). Blackwell Science Publishers.

Menden-Deuer, S., \& Lessard, E. J. (2000). Carbon to volume relationships for dinoflagellates, diatoms, and other protist plankton. Limnology \& Oceanography, 45(3), 569-579. https://doi.org/10.4319/1o.2000.45.3.0569.

Meybeck, M. (1996). River water quality, global ranges time and space variabilities. Verhandlungen - Internationale Vereinigung fur Theoretische und Angewandte Limnologie, 26, 81-96.

Meybeck, M. (2003). Global analysis of river systems: from Earth system controls to Anthropocene syndromes. Philosophical Transactions of the Royal Society of London B: Biological Sciences, 358(1440), 1935-1955. https://doi.org/10.1098 /rstb.2003.1379.

Moscuzza, C., Volpedo, A. V., Ojeda, C., \& Fernández Cirelli, A. (2007). Water quality index as a tool for river assessment in agricultural areas in the Pampean plains of Argentina. Journal of Urban \& Environmental Engineering, 1(1), 1825. https://doi.org/10.4090/juee.2007.v1n1.018025.

Mugni, H. (2008). Concentración de nutrientes y toxicidad de pesticidas en aguas superficiales de cuencas rurales. $\mathrm{PhD}$ Tesis: FCNyM, Universidad Nacional de La Plata.

Neal, C., Hilton, J., Wade, A. J., Neal, M., \& Wickham, H. (2006). Chlorophyll $a$ in the rivers of eastern England. Science of the Total Environment, 365(1-3), 84-104. https://doi. org/10.1016/j.scitotenv.2006.02.039.

Neal, C., Jarvie, H. P., Withers, P. J., Whitton, B. A., \& Neal, M. (2010). The strategic significance of wastewater sources to pollutant phosphorus levels in English rivers and to environmental management for rural, agricultural and urban catchments. Science of the Total Environment, 408(7), 1485-1500. https://doi.org/10.1016/j.scitotenv.2009.12.020.

Neschuk, N. C. (2001). Limnología del Río Salado (Buenos Aires) $y$ el uso de la tierra en su cuenca. PhD Tesis: FCNyM, Universidad Nacional de La Plata.

Padisák, J., \& G.-Tóth, L. (1991). Some aspects of the ecology of subdominant green algae in a large, nutrient limited shallow lake (Balaton, Hungary). Archiv für Protistenkunde, 139(1-4), 225-242. https://doi.org/10.1016/S0003-9365(11)80022-9.

Palmer, J., Suter, S. N., \& Aradas, R. D. (2002). The Río Salado Basin in Argentina: an integrated master plan. Water \& Environment Journal, 16(2), 141-146. https://doi. org/10.1111/j.1747-6593.2002.tb00385.x.

Picard, V., \& Lair, N. (2005). Spatio-temporal investigations on the planktonic organisms of the Middle Loire (France), during the low water period: biodiversity and community dynamics. Hydrobiologia, 551(1), 69-86. https://doi. org/10.1007/s10750-005-4451-4.

Pilkaitytë, R., Schoor, A., \& Schubert, H. (2004). Response of phytoplankton communities to salinity changes-a mesocosm approach. Hydrobiologia, 513(1), 27-38. https://doi. org/10.1023/B:hydr.0000018162.50270.54.

Poff, N. L., Allan, J. D., Bain, M. B., Karr, J. R., Prestegaard, K. L., Richter, B. D., Sparks, R. E., \& Stromberg, J. C. (1997). The natural flow regime. Bioscience, 47(11), 769-784. https://doi.org/10.2307/1313099.

Putt, M., \& Stoeckner, D. K. (1989). An experimentally determined carbon: volume ratio for marine "oligotrichous" ciliates from estuarine and coastal waters. Limnology \& Oceanography, 34(6), 1097-1103. https://doi.org/10.4319 /lo.1989.34.6.1097.

Reddy, K. R., \& De Laune, R. D. (2008). Biogeochemistry of wetlands: science and applications. Boca Raton, FL: CRC Press, Taylor \& Francis Group. https://doi.org/10.1201 19780203491454.

Reddy, K. R., Kadlec, R. H., Flaig, E., \& Gale, P. M. (1999). Phosphorus retention in streams and wetlands: a review. Critical Reviews in Environmental Science \& Technology, 29(1), 83-146. https://doi.org/10.1080/10643389991259182.

Reynolds, C. S., \& Descy, J.-P. (1996). The production, biomass and structure of phytoplankton in large rivers. Archiv für Hydrobiologie, Supplement Large Rivers, 10, 161-187.

Rojas Molina, F., \& José de Paggi, S. (2008). Zooplankton in the Paraná River floodplain (South America) before and after the invasion of Limnoperna fortunei (Bivalvia). Wetlands, 28(3), 695-702. https://doi.org/10.1672/07-179.1.

Rojo, A., Kruse, E., Laurencena, P., Deluchi, M., \& Carol, E. (2006). Relación de la capa freática y las obras de regulación en la región Vallimanca-Las Flores. Dissertation VIII Congreso Latinoamericano de Hidrología Subterránea. Asunción, Paraguay.

Rossetti, G., Viaroli, P., \& Ferrari, I. (2009). Role of abiotic and biotic factors in structuring the metazoan plankton community in a lowland river. River Research \& Applications, 25(7), 814-835. https://doi.org/10.1002/rra.1170.

Scarpati, O. E., Specha, L., \& Capriolo, A. (2002). Occurrence of severe floods in the Salado river basin, Buenos Aires Province, Argentina. Mitigation and Adaptation Strategies for Global Change, 7(3), 285-301. https://doi.org/10.1023 /A:1024427613595.

Schäfer, R. B., Kefford, B. J., Metzeling, L., Liess, M., Burgert, S., Marchant, R., Pettigrove, V., Goonan, P., \& Nugegoda, D. (2011). A trait database of stream invertebrates for the ecological risk assessment of single and combined effects of salinity and pesticides in South-East Australia. Science of the Total Environment, 409(11), 2055-2063. https://doi. org/10.1016/j.scitotenv.2011.01.053.

Schagerl, M., Drozdowski, I., Angeler, D. G., Hein, T., \& Preiner, S. (2009). Water age - a major factor controlling phytoplankton community structure in a reconnected dynamic floodplain (Danube, Regelsbrunn, Austria). Journal of Limnology, 68(2), 274-287. https://doi.org/10.4081/jlimnol.2009.274.

Shiel, R. J., \& Koste, W. (1983). Rotifer communities of billabongs in northern and south-eastern Australia. Hydrobiologia, 104(1), 41-47. https://doi.org/10.1007 /BF00045950. 
SMN (2016). Servicio Meteorológico Nacional, Argentina [http://www.smn.gov.ar/].

Sparks, R. E. (1995). Need for ecosystem management of large rivers and their floodplains. Bioscience, 168-182.

Sun, J., \& Liu, D. (2003). Geometric models for calculating cell biovolume and surface area for phytoplankton. Journal of Plankton Research, 25(11), 1331-1346. https://doi. org/10.1093/plankt/fbg096.

Tanco, R., \& Kruse, E. (2001). Prediction of seasonal water-table fluctuations in La Pampa and Buenos Aires, Argentina. Hydrogeology Journal, 39, 339-347.

Tartari, G. A., \& Mosello, R. (1997). Metodologia analitiche e conrolli di qualitá nel laboratorio chimico dell' instituto di idrobiologia. In Consiglio Nazionale delle Ricerche. Istituto Italiano: di Idrobiolgia. na.

Thorp, J. H., Black, A. R., \& Haag, K. H. (1994). Zooplancton assemblages in the Ohio River. Seasonal, tributary, and navigation dam effects. Canadian Journal of Fisheries \& Aquatic Sciences, 51(7), 1634-1643. https://doi.org/10.1139 /f94-164.

Turner, R. E., Rabalais, N. N., Justic, D., \& Dortch, Q. (2003). Global patterns of dissolved N, P and $\mathrm{Si}$ in large rivers. Biogeochemistry, 64(3), 297-317. https://doi.org/10.1023 /A:1024960007569.

Viglizzo, E. F., \& Frank, F. C. (2006). Ecological interactions, feedbacks, thresholds and collapses in the Argentine Pampas in response to climate and farming during the last century. Quaternary International, 158, 22-126.

Vilches, C., Giorgi, A., Mastrángelo, M., \& Ferrari, L. (2011). Non-point contamination homogenizes the water quality of Pampean streams. Bulletin of Environmental Contamination and Toxicology, 87(2), 147-151. https://doi.org/10.1007 /s00128-011-0312-1.

Wahl, D. H., Goodrich, J., Nannini, M. A., Dettmers, J. M., \& Soluk, D. A. (2008). Exploring riverine zooplankton in three habitats of the Illinois River ecosystem: where do they come from? Limnology \& Oceanography, 53(6), 2583-2593. https://doi.org/10.4319/lo.2008.53.6.2583.

Walker, B. H. (1992). Biodiversity and ecological redundancy. Conservation Biology, 6(1), 18-23. https://doi.org/10.1046 /j.1523-1739.1992.610018.x.
Weilhoefer, C. L., Pan, Y., \& Eppard, S. (2008). The effects of river floodwaters on floodplain wetland water quality and diatom assemblages. Wetlands, 28(2), 473-486. https://doi. org/10.1672/07-114.1.

Wetzel, R. G., \& Likens, G. E. (1991). Limnological analyses (2nd ed.). New York: Springer-Verlag. https://doi.org/10.1007 1978-1-4757-4098-1.

Williams, W. D. (1999). Salinization: a major threat to water resources in the arid and semi-arid regions of the world. Lakes \& Reservoirs, 4, 85-91.

Withers, P. J. A., \& Jarvie, H. P. (2008). Delivery and cycling of phosphorus in rivers: a review. Science of the Total Environment, 400(1-3), 379-395. https://doi.org/10.1016/j. scitotenv.2008.08.002.

Wolf, K. L., Noe, G. B., \& Ahn, C. (2013). Hydrologic connectivity to streams increases nitrogen and phosphorus inputs and cycling in soils of created and natural floodplain wetlands. Journal of Environmental Quality, 42(4), 1245-1255. https://doi.org/10.2134/jeq2012.0466.

Woltemade, C. J. (2000). Ability of restored wetlands to reduce nitrogen and phosphorus concentrations in agricultural drainage water. Journal of Soil \& Water Conservation, 55, 303-309.

Zalewski, M., Bis, B., Kapinska, M., Frankiewicz, P., \& Puchalski, W. (1998). The importance of the riparian ecotone and river hydraulics for sustainable basin-scale restoration scenarios. Aquatic Conservation: Marine \& Freshwater Ecosystems, 8(2), 287-307. https://doi.org/10.1002/(SICI)1099-0755 (199803/04)8:2<287::AID-AQC274>3.0.CO;2-R.

Zalewski, M. (2007). Ecohydrology as a concept and management tool. In C. King, J. Ramkissoon, M. Clüsener-Godt, \& Z. Adeel (Eds.), Water and ecosystems: managing water in diverse ecosystems to ensure human well-being (pp. 3953). Canada: UNU-INWEH UNESCO MAB.

Zalizniak, L., Kefford, B. J., \& Nugegoda, D. (2009). Effects of different ionic compositions on survival and growth of Physa acuta. Aquatic Ecology, 43(1), 145-156. https://doi. org/10.1007/s10452-007-9144-9. 